\section{National Epilepsy Awareness Month — November 2015}

Epilepsy is a brain disorder characterized by recurrent seizures; an estimated 2.9 million persons in the United States have active epilepsy (1). A seizure is a brief change in normal brain activity that changes awareness, behavior, or body movement. More than 30 different types of seizures have been described (2). A report in this issue characterizes seizures in children and adolescents aged 6-17 years in the United States.

Because seizures can affect anyone, members of the public need to know how to safely assist a person having a seizure. Not all seizures are emergencies, and most will end within a few minutes. The first response to witnessing a seizure should be to remain calm and provide care and comfort. A person with a convulsive seizure might cry out, fall, stiffen, shake, or lose awareness. If possible, the person should be helped to sit safely or should be guided gently to the floor. Once on the floor, a person should be turned on the side to keep the airway clear; nearby objects should be moved to prevent injury, and the head should be cushioned. A person witnessing a seizure in someone should call 911 if a seizure lasts more than 5 minutes, causes an injury, occurs in a person with another known condition (e.g., pregnancy or low blood sugar in diabetes), or causes a person to have difficulty breathing or waking after the seizure is over.

CDC works to improve the health and well-being of persons with epilepsy and to educate the public about this disorder (3). Additional information about providing first aid for seizures is available at http://www.cdc.gov/epilepsy/basics/first-aid. htm and http://www.epilepsy.com/start-here/seizure-first-aid.

\section{References}

1. CDC. Epilepsy fast facts. Atlanta, GA: US Department of Health and Human Services, CDC; 2015 . Available at http://www.cdc.gov/ epilepsy/basics/fast-facts.htm.

2. National Institute of Neurological Disorders and Stroke. Epilepsy: hope through research. Washington, DC: National Institutes of Health, National Institute of Neurological Disorders and Stroke; 2015. Available at http:// www.ninds.nih.gov/disorders/epilepsy/detail_epilepsy.htm\#3109_8.

3. CDC. Epilepsy. Atlanta, GA: US Department of Health and Human Services, CDC; 2015. Available at http://www.cdc.gov/epilepsy/index.html.

\section{Seizures in Children and Adolescents Aged 6-17 Years - United States, 2010-2014}

Wanjun Cui, $\mathrm{PhD}^{1}$; Rosemarie Kobau, $\mathrm{MPH}^{1}$; Matthew M. Zack, MD ${ }^{1}$; Sandra Helmers, $\mathrm{MD}^{1}$; Marshalyn Yeargin-Allsopp, $\mathrm{MD}^{2}$

A seizure is a brief change in normal electrical brain activity resulting in alterations in awareness, perception, behavior, or movement. Seizures affect persons of all ages, but are particularly common in childhood. There are many causes of seizures in children, including epilepsy; high fever (febrile seizures); head injuries; infections (e.g., malaria, meningitis, and gastrointestinal illness); metabolic, neurodevelopmental, and cardiovascular conditions; and complications associated with birth (1-3). Outcomes associated with single or recurring seizures in children vary by seizure type (febrile compared with nonfebrile) and multiple risk factors (age, illness, family history, and family context). Outcomes range from no complications to increased risk for behavioral problems, epilepsy, or sudden unexpected death (3-6). No nationally representative estimates have been reported for the number of U.S. children and adolescents with seizures, co-occurring conditions,

\author{
INSIDE \\ 1215 Gestational Weight Gain — United States, 2012 \\ and 2013 \\ 1221 Vital Signs: Multistate Foodborne Outbreaks - \\ United States, 2010-2014 \\ 1226 Notes from the Field: Primary Amebic \\ Meningoencephalitis Associated with Hot Spring \\ Exposure During International Travel — Seminole \\ County, Florida, July 2014 \\ 1227 Announcement \\ 1228 QuickStats
}

Continuing Education examination available at http://www.cdc.gov/mmwr/cme/conted_info.html\#weekly.

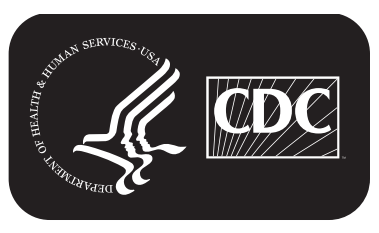

U.S. Department of Health and Human Services Centers for Disease Control and Prevention 
or health service utilization. To address these information gaps, $\mathrm{CDC}$ analyzed combined data on children and adolescents aged 6-17 years from the National Health Interview Survey (NHIS) for the period $2010-2014$. Overall, $0.7 \%$ of children and adolescents (weighted national estimate $=336,000$ ) were reported to have had at least one seizure during the preceding year. Compared with children and adolescents without seizures, a higher percentage of those with seizures were socially and economically disadvantaged. Children and adolescents with seizures had higher prevalences of various mental, developmental, physical, and functional co-occurring conditions than those without seizures; however, only $65.6 \%$ of those with seizures had visited a medical specialist (defined as a medical doctor who specializes in a particular medical disease or problem, other than an obstetrician/gynecologist, psychiatrist, or ophthalmologist) during the preceding 12 months. Public health agencies can work with other health and human service agencies to raise awareness about childhood seizures, implement strategies to prevent known causes and risk factors for seizures, study the associations between sociodemographic characteristics and seizure incidence, and ensure linkages for children with seizures to appropriate clinical and community providers.

NHIS is an ongoing annual, nationally representative multistage household survey of the U.S. civilian noninstitutionalized population (http://www.cdc.gov/nchs/nhis/about_nhis. htm). CDC analyzed combined 2010-2014 NHIS data from the Sample Child component (questions asked about one randomly selected child from each family in the NHIS), with an average final response rate of $70 \%$. Because these data do not distinguish the relatively large proportion of young children who experience usually benign febrile seizures* from those who have seizures of other etiologies ( 7 ), only children and adolescents aged 6-17 years were selected for analysis. Those whose parents provided a "Yes" answer to the survey question, "During the past 12 months, has [your child] had any of the following conditions?" and indicated "seizures" were identified as respondents with seizures.

Multiple outcomes reported by parents of those with and without seizures were examined, including indicators of food insecurity; co-occurring conditions (e.g., neurodevelopmental disabilities, recent infectious illnesses), functional limitations, and taking prescription medications; barriers to care, represented by delaying getting care and being unable to afford care in the past 12 months; access to care or health service utilization in the past 12 months; and the number of missed school days associated with any illness or injury.

Multiple logistic regression was used to calculate the prevalences and 95\% confidence intervals (CI) of co-occurring conditions and barriers and access to care, adjusted by sex, race/ ethnicity, family poverty income ratio, ${ }^{\dagger}$ and mother's highest level of education, for children with and without seizures.

\footnotetext{
* Febrile seizures usually occur in children aged 6 months -5 years and affect about $2 \%-5 \%$ of children in that age range. Febrile seizures are usually benign and children with uncomplicated febrile seizures rarely go on to develop epilepsy $(7)$.

$\dagger$ A ratio of the family's income to the appropriate federal poverty threshold. Each person or family is assigned one out of 48 possible poverty thresholds. Thresholds vary according to family size and ages of family members. If total family income is less than the threshold appropriate for that family, the family is in poverty.
}

The MMWR series of publications is published by the Center for Surveillance, Epidemiology, and Laboratory Services, Centers for Disease Control and Prevention (CDC), U.S. Department of Health and Human Services, Atlanta, GA 30329-4027.

Suggested citation: [Author names; first three, then et al., if more than six.] [Report title]. MMWR Morb Mortal Wkly Rep 2015;64:[inclusive page numbers]

\author{
Centers for Disease Control and Prevention \\ Thomas R. Frieden, MD, MPH, Director \\ Harold W. Jaffe, MD, MA, Associate Director for Science \\ Joanne Cono, MD, ScM, Director, Office of Science Quality \\ Chesley L. Richards, MD, MPH, Deputy Director for Public Health Scientific Services \\ Michael F. Iademarco, MD, MPH, Director, Center for Surveillance, Epidemiology, and Laboratory Services
}

MMWR Editorial and Production Staff (Weekly)

Sonja A. Rasmussen, MD, MS, Editor-in-Chief

Charlotte K. Kent, PhD, MPH, Executive Editor Jacqueline Gindler, MD, Editor

Teresa F. Rutledge, Managing Editor

Douglas W. Weatherwax, Lead Technical Writer-Editor

Soumya Dunworth, PhD, Teresa M. Hood, MS,

\section{MMWR Editorial Board}

Timothy F. Jones, MD, Chairman

Matthew L. Boulton, MD, MPH

Virginia A. Caine, MD

Katherine Lyon Daniel, $\mathrm{PhD}$

Jonathan E. Fielding, MD, MPH, MBA

David W. Fleming, MD

\author{
William E. Halperin, MD, DrPH, MPH \\ King K. Holmes, MD, PhD \\ Robin Ikeda, MD, MPH \\ Rima F. Khabbaz, MD \\ Phyllis Meadows, PhD, MSN, RN \\ Jewel Mullen, MD, MPH, MPA
}

Martha F. Boyd, Lead Visual Information Specialist

Maureen A. Leahy, Julia C. Martinroe, Stephen R. Spriggs, Moua Yang,

Visual Information Specialists

Quang M. Doan, MBA, Phyllis H. King,

Teresa C. Moreland, Terraye M. Starr,

Information Technology Specialists
Jeff Niederdeppe, $\mathrm{PhD}$

Patricia Quinlisk, MD, MPH

Patrick L. Remington, MD, MPH Carlos Roig, MS, MA

William L. Roper, MD, MPH

William Schaffner, MD 
Statistical software was used to account for the NHIS complex survey design and sample child weights. Prevalences were considered statistically significantly different if their CIs did not overlap.

During 2010-2014, parents of $0.7 \%$ of children and adolescents aged 6-17 years (weighted national estimate $=336,000$ ) reported that their child had seizures during the past 12 months (Table 1). Children and adolescents with seizures were significantly more likely than those without seizures to live in poverty and low-income families or households (41.6\% compared with $28.6 \%$ ), and were less likely to have mothers or fathers with a bachelor's degree or higher $(20.4 \%$ compared with $30.6 \%$ and $22.4 \%$ compared with $34.0 \%$, respectively), or to live in nuclear families or households $\$$ (30.3\% compared with

\footnotetext{
\$A nuclear family consists of one or more children living with two parents who are married to one another and are each biological or adoptive parents to all children in the family.
}

TABLE 1. Number and weighted percentage of children and adolescents aged 6-17 years with seizures and without seizures, by selected characteristics - National Health Interview Survey, 2010-2014

\begin{tabular}{|c|c|c|c|c|}
\hline \multirow[b]{2}{*}{ Characteristic } & \multicolumn{2}{|c|}{ With seizures } & \multicolumn{2}{|c|}{ Without seizures } \\
\hline & No. in sample & Weighted \% (95\% CI) & No. in sample & Weighted \% (95\% Cl) \\
\hline Total & 298 & 0.7 & 41,711 & 99.3 \\
\hline $\begin{array}{l}\text { Sex } \\
\text { Male } \\
\text { Female }\end{array}$ & $\begin{array}{l}147 \\
151\end{array}$ & $\begin{array}{l}46.9(39.8-54.1) \\
53.1(45.9-60.2)\end{array}$ & $\begin{array}{l}21,552 \\
20,159\end{array}$ & $\begin{array}{l}51.2(50.6-51.8) \\
48.8(48.2-49.4)\end{array}$ \\
\hline $\begin{array}{l}\text { Race/Ethnicity } \\
\text { White, non-Hispanic } \\
\text { Black, non-Hispanic } \\
\text { Hispanic } \\
\text { Other }\end{array}$ & $\begin{array}{r}125 \\
54 \\
85 \\
34\end{array}$ & $\begin{array}{r}50.7(43.0-58.3) \\
16.3(11.5-22.7) \\
23.3(17.7-29.9) \\
\quad 9.7(6.5-14.2)\end{array}$ & $\begin{array}{r}18,761 \\
6,445 \\
12,145 \\
4,360\end{array}$ & $\begin{array}{r}54.8(53.7-55.9) \\
13.8(13.1-14.4) \\
22.7(21.7-23.7) \\
8.7(8.3-9.2)\end{array}$ \\
\hline $\begin{array}{l}\text { Family poverty income ratio* } \\
\leq 129 \% \\
130 \%-349 \% \\
\geq 350 \%\end{array}$ & $\begin{array}{r}123 \\
111 \\
64\end{array}$ & $\begin{array}{l}41.6(34.4-49.1)^{\dagger} \\
37.0(29.8-44.7) \\
21.5(16.2-27.9)^{\dagger}\end{array}$ & $\begin{array}{l}12,168 \\
16,257 \\
13,286\end{array}$ & $\begin{array}{l}28.6(27.7-29.5) \\
38.1(37.4-38.8) \\
33.3(32.3-34.4)\end{array}$ \\
\hline $\begin{array}{l}\text { Mother's education } \\
\text { Less than high school diploma } \\
\text { High school } \\
\text { Some college } \\
\text { Bachelor's degree or higher }\end{array}$ & $\begin{array}{r}48 \\
65 \\
103 \\
57\end{array}$ & $\begin{array}{l}16.4(11.7-22.4) \\
25.7(19.5-33.1) \\
37.5(30.6-45.0) \\
20.4(14.9-27.4)^{\dagger}\end{array}$ & $\begin{array}{r}6,486 \\
8,606 \\
12,108 \\
10,501\end{array}$ & $\begin{array}{l}15.2(14.5-16.0) \\
21.7(21.1-22.3) \\
32.5(31.8-33.3) \\
30.6(29.6-31.6)\end{array}$ \\
\hline $\begin{array}{l}\text { Father's education } \\
\text { Less than high school diploma } \\
\text { High school } \\
\text { Some college } \\
\text { Bachelor's degree or higher }\end{array}$ & $\begin{array}{l}37 \\
43 \\
55 \\
34\end{array}$ & $\begin{array}{l}19.3(13.2-27.4) \\
24.5(17.3-33.3) \\
33.8(25.6-43.1) \\
22.4(16.1-30.4)^{\dagger}\end{array}$ & $\begin{array}{l}5,066 \\
7,135 \\
7,351 \\
8,503\end{array}$ & $\begin{array}{l}15.3(14.5-16.1) \\
24.2(23.4-25.1) \\
26.4(25.6-27.2) \\
34.0(32.9-35.3)\end{array}$ \\
\hline $\begin{array}{l}\text { Family structure } \\
\text { Single-parent family } \\
\text { Nuclear family } \\
\text { Blending or cohabiting family } \\
\text { Extended family/Other }\end{array}$ & $\begin{array}{r}74 \\
80 \\
43 \\
101\end{array}$ & $\begin{array}{l}23.1(17.6-29.8) \\
30.3(24.0-37.4)^{\dagger} \\
16.5(11.8-22.6) \\
30.0(24.1-36.8)\end{array}$ & $\begin{array}{r}8,180 \\
15,333 \\
4,746 \\
13,422\end{array}$ & $\begin{array}{l}17.9(17.3-18.4) \\
41.9(41.1-42.8) \\
12.7(12.2-13.2) \\
27.6(27.0-28.1)\end{array}$ \\
\hline $\begin{array}{l}\text { Worried food would run out b } \\
\text { Often true or sometimes true } \\
\text { Never true }\end{array}$ & $\begin{array}{c}\text { asked in } 2011-2 \\
79 \\
157\end{array}$ & 4) $\begin{array}{l}34.5(27.1-42.6)^{\dagger} \\
65.5(57.4-72.9)^{\dagger}\end{array}$ & $\begin{array}{r}8,246 \\
26,143\end{array}$ & $\begin{array}{l}22.9(22.1-23.6) \\
77.1(76.4-77.9)\end{array}$ \\
\hline $\begin{array}{l}\text { Food did not last before had } n \\
\text { Often true or sometimes true } \\
\text { Never true }\end{array}$ & $\begin{array}{r}1-2014) \\
74 \\
162\end{array}$ & $\begin{array}{l}30.9(23.3-39.5)^{\dagger} \\
69.1(60.5-76.7)^{\dagger}\end{array}$ & $\begin{array}{r}6,945 \\
27,445\end{array}$ & $\begin{array}{l}19.2(18.5-19.8) \\
80.8(80.2-81.5)\end{array}$ \\
\hline $\begin{array}{l}\text { Could not afford to eat balanc } \\
\text { Often true or sometimes true } \\
\text { Never true }\end{array}$ & $\begin{array}{r}63 \\
173\end{array}$ & $\begin{array}{l}24.3(18.4-31.4)^{\dagger} \\
75.7(68.6-81.6)^{\dagger}\end{array}$ & $\begin{array}{r}5,552 \\
28,832\end{array}$ & $\begin{array}{l}14.9(14.3-15.4) \\
85.1(84.6-85.7)\end{array}$ \\
\hline $\begin{array}{l}\text { Insurance status } \\
\text { Private } \\
\text { Medicaid/Medicare } \\
\text { Not covered } \\
\text { Other }\end{array}$ & $\begin{array}{r}129 \\
124 \\
14 \\
30\end{array}$ & $\begin{array}{r}46.4(39.2-53.7)^{\dagger} \\
36.1(29.8-42.8)^{\dagger} \\
12.7(8.3-19.0)^{9}\end{array}$ & $\begin{array}{r}22,134 \\
11,317 \\
3,591 \\
4,492\end{array}$ & $\begin{array}{r}56.3(55.3-57.3) \\
26.1(25.3-27.0) \\
7.4(7.1-7.8) \\
10.2(9.7-10.7)\end{array}$ \\
\hline
\end{tabular}

Abbreviation: $\mathrm{Cl}$ = confidence interval.

* A ratio of the family's income to the appropriate federal poverty threshold. Each person or family is assigned one out of 48 possible poverty thresholds. Thresholds vary according to family size and ages of family members. If total family income is less than the threshold appropriate for that family, the family is in poverty.

† Estimate is statistically significantly different $(p<0.01)$ from the "Without seizures" group for the same condition/variable.

$\S$ Estimate suppressed because relative standard error was $\geq 30 \%$.

I Estimate has a relative standard error of $\geq 20 \%$ and $<30 \%$. 
41.9\%). Parents of children with seizures also were more likely than parents of children without seizures to report worrying that food would run out (34.5\% compared with $22.9 \%)$ or that food they bought would not last until they had money to get more (30.9\% compared with $19.2 \%)$.

Co-occurring conditions were generally more frequently reported by parents of children and adolescents with seizures than by those without seizures (Table 2). Children with seizures had higher reported prevalences of mental or developmental co-occurring conditions, including learning disabilities (43.7\% compared with $8.2 \%$ ); other types of developmental delay (32.3\% compared with $4.3 \%)$; intellectual disability (22.9\% compared with $1.0 \%$ ); and attention deficit hyperactivity disorder/attention deficit disorder (19.3\% compared with $10.3 \%)$ than did children without seizures. Parents of children with seizures more frequently reported that their children had headaches or migraines $(23.7 \%$ compared with $7.0 \%)$, hay fever (19.0\% compared with $11.2 \%)$, and stuttering or stammering (11.3\% compared with $1.6 \%)$. In addition, children with seizures were more frequently reported to have an impairment or health problem that limited their abilities to crawl, walk, run, or play ( $23.7 \%$ compared with $1.9 \%)$; to require special equipment because of impairment or health problems $(21.4 \%$ compared with $1.1 \%$ ); and to have taken prescription medication for $\geq 3$ months (68.7\% compared with $15.6 \%$ ) (Table 2$)$.

A significantly higher percentage of parents of children and adolescents with seizures reported delays in getting health care than did parents of children without seizures (14.4\% compared with $8.8 \%$ ) (Table 3). Children and adolescents with seizures were significantly more likely to see different types of health care providers, but $34.4 \%$ had not seen a medical specialist during the past 12 months. During the same time period, $41.0 \%$ of children and adolescents with seizures visited an emergency department, compared with $15.4 \%$ of children and adolescents without seizures. Children and adolescents with seizures reportedly missed six or more school days associated with any illness or injury significantly more frequently than did children and adolescents without seizures (41.9\% compared with 14.3\%) (Table 3).

TABLE 2. Adjusted* prevalences of selected co-occurring health conditions for children and adolescents aged 6-17 years, with and without seizures - National Health Interview Survey, 2010-2014

\begin{tabular}{|c|c|c|c|c|}
\hline \multirow[b]{2}{*}{ Condition } & \multicolumn{2}{|c|}{ With seizures } & \multicolumn{2}{|c|}{ Without seizures } \\
\hline & No. in sample & Weighted \% (95\% CI) & No. in sample & Weighted \% (95\% Cl) \\
\hline Learning disability & 138 & $43.7(36.6-51.2)^{\dagger}$ & 3,498 & $8.2(7.9-8.6)$ \\
\hline Intellectual disability & 70 & $22.9(17.5-29.4)^{\dagger}$ & 475 & $1.0(0.9-1.2)$ \\
\hline Other developmental delay & 96 & $32.3(25.6-39.8)^{\dagger}$ & 1,724 & $4.3(4.1-4.6)$ \\
\hline Attention deficit hyperactivity disorder/Attention deficit disorder & 69 & $19.3(14.2-25.5)^{\dagger}$ & 4,227 & $10.3(9.9-10.7)$ \\
\hline Cerebral palsy & 31 & $15.0(9.9-22.1)^{\S}$ & 78 & $0.2(0.1-0.3)$ \\
\hline Autism spectrum disorder & 18 & $8.1(4.8-13.5)^{\S}$ & 405 & $1.2(1.0-1.3)$ \\
\hline Asthma & 62 & $19.0(14.1-25.0)$ & 7,137 & $16.4(15.8-16.9)$ \\
\hline Hay fever, past 12 mos. & 51 & $19.0(13.4-26.3)^{\dagger}$ & 4,565 & $11.2(10.7-11.7)$ \\
\hline Respiratory allergy, past 12 mos. & 51 & $16.1(11.6-21.9)$ & 5,047 & $12.3(11.9-12.8)$ \\
\hline Food/Digestive allergy, past 12 mos. & 30 & $10.5(6.9-15.7)^{\S}$ & 2,202 & $5.5(5.3-5.9)$ \\
\hline Eczema/skin allergy, past 12 mos. & 43 & $14.0(9.5-20.0)$ & 4,688 & $11.7(11.3-12.1)$ \\
\hline Diarrhea/colitis, past 12 mos. & 23 & $8.1(4.9-13.4)^{\S}$ & 521 & $1.3(1.1-1.4)$ \\
\hline Anemia, past 12 mos. & 17 & $5.8(3.2-10.0)^{\S}$ & 433 & $0.9(0.8-1.1)$ \\
\hline Had three or more ear infections, past 12 mos. & 25 & $8.2(5.2-12.6)^{\S}$ & 1,370 & $3.3(3.1-3.5)$ \\
\hline Had frequent headaches/migraines, past 12 mos. & 76 & $23.7(18.3-30.2)^{\dagger}$ & 3,033 & $7.0(6.6-7.3)$ \\
\hline Had head/chest cold, past 2 wks. & 40 & $12.2(8.3-17.5)$ & 5,220 & $12.8(12.4-13.3)$ \\
\hline Had stomach illness with vomiting/diarrhea, past 2 wks. & 26 & $7.5(4.7-11.7)^{\S}$ & 1,980 & $5.1(4.9-5.4)$ \\
\hline Stuttered/stammered, past 12 mos. & 44 & $11.3(7.7-16.2)^{\dagger}$ & 707 & $1.6(1.5-1.8)$ \\
\hline Trouble seeing & 37 & $12.4(8.1-18.6)^{\S}$ & 1,373 & $3.2(3.0-3.4)$ \\
\hline Need special equipment due to impairment/health problem & 56 & $21.4(16.0-28.0)^{\dagger}$ & 464 & $1.1(1.0-1.3)$ \\
\hline Impairment/Health problem limiting crawl/walk/run/play & 71 & $23.7(18.0-30.5)^{\dagger}$ & 795 & $1.9(1.7-2.1)$ \\
\hline Taken prescription medication for $\geq 3$ mos. & 197 & $68.7(61.4-75.3)^{\dagger}$ & 6,361 & $15.6(15.1-16.1)$ \\
\hline \multicolumn{5}{|l|}{ Hearing status without hearing aid or other listening device } \\
\hline Excellent & 145 & $70.3(62.5-77.1)^{\dagger}$ & 25,875 & $80.0(79.3-80.6)$ \\
\hline Good & 61 & $20.7(14.9-27.9)$ & 6,148 & $17.6(17.0-18.2)$ \\
\hline Trouble hearing/deaf & 26 & $9.0(5.5-14.5)^{\S}$ & 762 & $2.4(2.2-2.7)$ \\
\hline \multicolumn{5}{|l|}{ Health condition compared with 12 mos. ago } \\
\hline Better & 81 & $26.0(19.9-33.3)^{\dagger}$ & 8,347 & $18.2(17.7-18.7)$ \\
\hline Worse & 32 & $10.7(7.0-16.0)^{\S}$ & 588 & $1.4(1.2-1.6)$ \\
\hline Same & 184 & $63.2(55.8-70.1)^{\dagger}$ & 32,755 & 80.4 (79.9-80.9) \\
\hline
\end{tabular}

Abbreviation: $\mathrm{Cl}=$ confidence interval.

* Adjusted for sex, race/ethnicity, family poverty income ratio, and mother's education.

† Estimate is statistically significantly different $(\mathrm{p}<0.01)$ from the "Without seizures" group for the same condition/variable.

$\S$ Estimate has a relative standard error of $\geq 20 \%$ and $<30 \%$. 


\section{Discussion}

Seizures in children and adolescents vary by cause, severity, and impact. The risk for some seizures can be prevented or reduced by eliminating their causes, such as ensuring proper prenatal and perinatal care and preventing head injuries. The findings in this report indicate that seizures affect $0.7 \%$ of children and adolescents aged 6-17 years, and, relative to the general population, children and adolescents with seizures are socially and economically disadvantaged, more likely to have co-occurring conditions, and more likely to face barriers to care.

The higher observed prevalence of co-occurring conditions is consistent with previous research that has shown a higher prevalence of neurodevelopmental conditions and behavior problems among some children with seizures (3-6). In this analysis, approximately two in five children and adolescents with seizures were reported to have a learning disability and $20 \%-30 \%$ of them had an intellectual disability, attention deficit hyperactivity disorder/attention deficit disorder, or other developmental disorder. Associations between seizures and these conditions might be bidirectional, sharing some common pathophysiological mechanisms (8). Headaches,

\footnotetext{
For example, a genetic mutation might disrupt neuronal development, resulting in seizures, autism spectrum disorder, or both, enhancing the progression of negative outcomes associated with either condition $(8)$.
}

TABLE 3. Adjusted* prevalences of barriers and access to health care variables for children and adolescents aged 6-17 years, with and without seizures - National Health Interview Survey, 2010-2014

\begin{tabular}{|c|c|c|c|c|}
\hline \multirow[b]{2}{*}{ Barrier/Variable } & \multicolumn{2}{|c|}{ With seizures } & \multicolumn{2}{|c|}{ Without seizures } \\
\hline & No. in sample & Weighted \% (95\% CI) & No. in sample & Weighted \% (95\% Cl) \\
\hline Delayed getting care for any reason, past 12 mos. $^{\dagger}$ & 45 & $14.4(10.1-20.1)^{\S}$ & 3,736 & $8.8(8.4-9.2)$ \\
\hline Didn't get something needed because you couldn't afford it, past 12 mos." & 49 & $15.6(11.1-21.6)$ & 4,144 & $11.5(11.1-12.0)$ \\
\hline Saw/talked to eye doctor, past 12 mos. & 123 & $40.3(33.7-47.2)^{\S}$ & 13,225 & $32.2(31.5-32.9)$ \\
\hline Saw/talked to foot doctor, past 12 mos. & 25 & $8.7(5.3-13.8)^{* *}$ & 1,020 & $2.4(2.2-2.6)$ \\
\hline Saw/talked to therapist (PT/OT/etc.), past 12 mos. & 100 & $34.4(27.6-41.8)^{\S}$ & 2,648 & $6.8(6.4-7.1)$ \\
\hline Saw/talked to a NP/PA, past 12 mos. & 94 & $38.1(30.7-46.0)^{\S}$ & 6,112 & $16.3(15.7-16.9)$ \\
\hline Saw/talked to mental health professional, past 12 mos. & 72 & $22.7(17.1-29.6)^{\S}$ & 3,638 & $8.5(8.1-8.8)$ \\
\hline Saw/talked to a medical specialist, past 12 mos. $^{\dagger \dagger}$ & 172 & $65.6(58.6-72.0)^{\S}$ & 5,703 & $14.4(13.9-14.8)$ \\
\hline Saw/talked to a general doctor, past 12 mos. & 265 & $92.4(88.7-95.0)^{\S}$ & 32,885 & $81.2(80.6-81.8)$ \\
\hline $\begin{array}{l}\text { Saw/talked to a doctor who treats both children and adults (asked among } \\
\text { those who saw/talked to a general doctor) }\end{array}$ & 123 & $43.4(35.8-51.4)$ & 13,955 & $39.7(38.7-40.7)$ \\
\hline $\begin{array}{l}\text { Saw/talked to doctor for emotional/behavioral problem (asked among those } \\
\text { who saw/talked to a general doctor) }\end{array}$ & 50 & $16.8(11.9-23.3)^{\S}$ & 2,135 & $6.3(5.9-6.6)$ \\
\hline Had well-child checkup, past 12 mos. & 241 & $81.5(75.1-86.5)$ & 31,284 & $77.5(76.8-78.1)$ \\
\hline Received home care from health professional, past 12 mos. & 25 & $10.5(6.6-16.2)^{* *}$ & 212 & $0.5(0.4-0.6)$ \\
\hline \multicolumn{5}{|l|}{ Number of times in emergency department, past 12 mos. } \\
\hline None & 161 & $59.1(51.3-66.4)^{\S}$ & 35,036 & $84.7(84.1-85.2)$ \\
\hline 1 & 63 & $21.1(15.7-27.7)^{\S}$ & 4,419 & $10.5(10.0-10.9)$ \\
\hline$\geq 2$ & 72 & $19.9(14.7-26.2)^{\S}$ & 2,036 & $4.9(4.6-5.2)$ \\
\hline \multicolumn{5}{|l|}{ Total number of office visits, past 12 mos. } \\
\hline None or 1 & 37 & $12.8(8.5-18.8)^{* *}$ & 15,704 & $36.2(35.5-36.8)$ \\
\hline $2-3$ & 71 & $21.2(15.9-27.6)^{\S}$ & 15,397 & $38.1(37.4-38.7)$ \\
\hline $4-5$ & 53 & $17.7(12.9-23.7)$ & 5,247 & $13.3(12.9-13.8)$ \\
\hline $6-7$ & 42 & $16.0(11.0-22.7)^{\S}$ & 1,904 & $4.8(4.5-5.1)$ \\
\hline $8-12$ & 46 & $15.4(10.9-21.4)^{\S}$ & 1,775 & $4.6(4.3-4.9)$ \\
\hline$\geq 13$ & 46 & $17.0(11.9-23.6)^{\S}$ & 1,255 & $3.1(2.9-3.4)$ \\
\hline \multicolumn{5}{|l|}{ Time since last saw/talked to health professional } \\
\hline$\leq 6$ months & 260 & $89.3(84.2-92.9)^{\S}$ & 28,697 & 70.7 (70.1-71.3) \\
\hline$>6$ months or never & 36 & $10.7(7.1-15.8)^{* *}$ & 12,627 & $29.3(28.7-29.9)$ \\
\hline \multicolumn{5}{|l|}{ School days missed due to illness/injury, past 12 mos. } \\
\hline Didn't go to school or none & 60 & $20.7(14.9-28.1)^{\S}$ & 13,007 & $29.6(29.0-30.3)$ \\
\hline $1-2$ days & 44 & $16.5(11.8-22.7)^{\S}$ & 11,877 & $29.8(29.2-30.4)$ \\
\hline $3-5$ days & 66 & $20.8(15.2-27.9)$ & 10,642 & $26.3(25.7-27.0)$ \\
\hline 6-10 days & 50 & $17.9(12.8-24.5)^{\S}$ & 3,941 & $9.8(9.4-10.2)$ \\
\hline$\geq 11$ days & 73 & $24.0(18.5-30.5)^{\S}$ & 1,885 & $4.5(4.2-4.8)$ \\
\hline
\end{tabular}

Abbreviations: $\mathrm{Cl}$ = confidence interval; NP/PA = nurse practitioner/physician's assistant; PT/OT = physical therapist/occupational therapist.

* Adjusted for sex, race/ethnicity, family poverty-income ratio, and mother's education.

† Including the following reasons: couldn't get through on the phone, couldn't get appointment soon enough, wait was too long in doctor's office, not open when able to go, and no transportation.

$\S$ Estimate is statistically significantly different $(p<0.01)$ from the "Without seizures" group for the same condition/variable.

II Including the following situations: prescription medicine, follow-up care (only asked in 2011-2014), seeing a specialist (only asked in 2011-2014), receiving mental health care/counseling, dental care, and eyeglasses.

** Estimate has a relative standard error $\geq 20 \%$ and $<30 \%$

${ }^{\dagger \dagger}$ A medical doctor who specializes in a particular medical disease or problem (other than obstetrician/gynecologist, psychiatrist, or ophthalmologist). 
including migraines, hay fever, and functional disabilities also reportedly affected about one in five children and adolescents with seizures.

Although most children and adolescents with seizures had recently seen a general doctor, they frequently require the care of a specialist, such as a neurologist, and parents of approximately one third of those with seizures reported that they had not recently seen or talked to a medical specialist. Parents reported delays in obtaining care associated with cost and other factors, such as lack of transportation. Higher rates of home care might be associated with severity of co-occurring conditions or transportation barriers. Higher rates of emergency department use might reflect seizure severity, or associated conditions, barriers to routine health care, or other unmet caregiver needs. For example, caregivers might not understand seizure symptoms, or they might be uncomfortable with providing appropriate seizure response.

Overall, parents of children and adolescents with seizures reported higher prevalences of co-occurring conditions; these and the health care utilization patterns and social disadvantages reported by parents of children and adolescents with seizures highlight unmet needs and gaps in care. Children and adolescents with seizures might need coordinated care that ensures accurate diagnosis of seizures and any co-occurring conditions, and that links caregivers with other community organizations to improve health outcomes $(9,10)$.

The findings in this study are subject to at least four limitations. First, the percentage of children and adolescents with seizures was ascertained through parent reports, which were not corroborated by other sources, and might be subject to misclassification or response biases. Second, this study might inadvertently include children and adolescents with febrile seizures. However, because febrile seizures usually occur in children aged 6 months -5 years ( 7 ), limiting analyses to children and adolescents aged 6-17 years should have excluded almost all children with febrile seizures. Third, because NHIS data are cross-sectional, causal relationships between seizures and some of the variables cannot be established. Finally, because NHIS does not ask about seizure type and frequency in children and adolescents, it is not possible to confirm whether children and adolescents with reported seizures had epilepsy, or to determine the etiology of the seizure or seizures.

Public health agencies can work with other health and human service agencies to raise awareness about seizures in children and adolescents (e.g., educate parents and school personnel), implement strategies to prevent known causes and risk factors for seizures (e.g., head injuries), study the associations between sociodemographic characteristics and seizure incidence, and ensure linkages to appropriate clinical and community providers for children and adolescents who experience seizures.

\section{Summary}

What is already known on this topic?

Children and adolescents with seizures can have more associated mental, developmental, and behavioral problems than children and adolescents without seizures. No nationally representative estimates of seizure burden and health service utilization for children and adolescents aged 6-17 years in the United States have been reported.

What is added by this report?

According to $2010-2014$ NHIS data, seizures affected $0.7 \%$ of children and adolescents aged 6-17 years and, relative to the general population, those with seizures were socially and economically disadvantaged, more likely to have co-occurring conditions, and more likely to face barriers to care.

What are the implications for public health practice?

Public health agencies can work with other health and human service agencies to raise awareness about seizures that occur in children and adolescents (e.g., educate parents and school personnel), implement strategies to prevent known causes and risk factors for seizures (e.g., head injuries), study the associations between sociodemographic characteristics and seizure incidence, and ensure linkages for those with seizures to appropriate clinical and community providers.

${ }^{1}$ Division of Population Health, National Center for Chronic Disease Prevention and Health Promotion, CDC; ${ }^{2}$ National Center on Birth Defects and Developmental Disabilities, CDC.

Corresponding author: Wanjun Cui, wtd9@cdc.gov, 770-488-5853.

\section{References}

1. Martin ET, Kerin T, Christakis DA, et al. Redefining outcome of first seizures by acute illness. Pediatrics 2010;126:e1477-84.

2. Fox CK, Glass HC, Sidney S, Lowenstein DH, Fullerton HJ. Acute seizures predict epilepsy after childhood stroke. Ann Neurol 2013;74:249-56.

3. Yeargin-Allsopp M, Boyle C, van Naarden-Braun K, Trevathan E. The epidemiology of developmental disabilities. In: Accardo PJ, ed. Capute and Accardo's neurodevelopmental disabilities in infancy and childhood. Baltimore, MD: Paul H. Brookes Publishing Co; 2008:61-104.

4. Austin JK, Perkins SM, Johnson CS, et al. Behavior problems in children at time of first recognized seizure and changes over the following 3 years. Epilepsy Behav 2011;21:373-81.

5. Hesdorffer DC, Crandall LA, Friedman D, Devinsky O. Sudden unexplained death in childhood: A comparison of cases with and without a febrile seizure history. Epilepsia 2015;56:1294-300.

6. Fastenau PS, Johnson CS, Perkins SM, et al. Neuropsychological status at seizure onset in children: risk factors for early cognitive deficits. Neurology 2009;73:526-34.

7. Vestergaard M, Christensen J. Register-based studies on febrile seizures in Denmark. Brain Dev 2009;31:372-7.

8. Stafstrom CE, Benke TA. Autism and epilepsy: exploring the relationship using experimental models. Epilepsy Curr 2015;15:206-10.

9. Kenney MK, Mann M. Assessing systems of care for US children and adolescents with epilepsy/seizure disorder. Epilepsy Res Treat 2013; 2013:825824.

10. Council on Children with Disabilities and Medical Home Implementation Project Advisory Committee, 2014. Patient- and family-centered care coordination: a framework for integrating care for children and youth across multiple systems. Pediatrics 2014;133:e1451-60. 


\title{
Gestational Weight Gain — United States, 2012 and 2013
}

\author{
Nicholas P. Deputy, MPH ${ }^{1,2,3}$; Andrea J. Sharma, $\mathrm{PhD}^{1}$; Shin Y. Kim, $\mathrm{MPH}^{1}$
}

The weight a woman gains during pregnancy, known as gestational weight gain (GWG), has important health implications for both mother and child (1). The Institute of Medicine (IOM) provides GWG recommendations that promote optimal health by balancing risks associated with too much or too little GWG and are specific to a woman's prepregnancy body mass index (BMI; weight $[\mathrm{kg}] /$ height $\left.[\mathrm{m}]^{2}\right)(1)$. In a recent study, $21 \%$ of pregnant women gained less than the recommended amount of weight, and $47 \%$ gained more than the recommended amount; however, state-specific prevalence was not examined (2). To estimate state-specific prevalence of GWG below, within, and above recommendations (referred to as inadequate, appropriate, and excessive, respectively), CDC analyzed 2013 birth data for U.S. resident women who delivered full-term (37-41 weeks gestation), singleton infants from 43 jurisdictions (41 states, New York City, and the District of Columbia [DC]) that used the 2003 revised birth certificate, which collects maternal height, prepregnancy weight, and delivery weight. In addition, 2012 data from the Pregnancy Risk Assessment Monitoring System (PRAMS) were analyzed to estimate prevalence for five states with available data that had not yet adopted the 2003 birth certificate. Overall, 32.1\% of women had appropriate GWG. States varied in prevalence of inadequate (range $=12.6 \%-25.5 \%$ ), appropriate $($ range $=26.2 \%-39.0 \%)$, and excessive $($ range $=38.2 \%-$ $54.7 \%$ ) GWG. The prevalence of inadequate GWG was $\geq 20 \%$ in 20 states and New York City; the prevalence of excessive GWG was $\geq 50 \%$ in 17 states. Stratification by prepregnancy BMI category indicated variation by state persisted; notably, overweight women had the highest prevalence of excessive GWG in nearly every state. Given the high prevalence of excessive GWG and its associated risks, including macrosomia and maternal obsesity (1), effective interventions to prevent excessive GWG during pregnancy are needed.

The primary data source was 2013 National Vital Statistics System birth data, a census of all births, for jurisdictions using the 2003 revision of the U.S. Standard Certificate of Live Birth, ${ }^{*}$ which collects the maternal height, prepregnancy weight, and delivery weight data needed to examine GWG in relation to the BMI-specific IOM recommendations. Height and weight data are self-reported or abstracted from the medical record. The previous (1989) birth certificate version reports only total GWG (self-reported or abstracted from the medical record), and therefore, cannot be used to examine

\footnotetext{
* Additional information available at: http://www.cdc.gov/nchs/births.htm.
}

GWG in relation to BMI-specific recommendations. As of January 1, 2013, 41 states, ${ }^{\dagger}$ New York City, and DC had adopted the 2003 birth certificate. Data from PRAMS for 2012 were analyzed for five states $\$$ that had yet to transition to the 2003 birth certificate and that had PRAMS data available. PRAMS is an ongoing, state-based surveillance system that systematically surveys a stratified, random sample of mothers from birth certificates. ${ }^{* *}$ At approximately 4 months postpartum, participating mothers complete a questionnaire that assesses pregnancy-related health characteristics, including height and prepregnancy weight. Questionnaire data are linked with birth certificate data, including GWG, and are weighted to represent all women delivering live infants in each state. For this report, women were included if they were U.S. residents delivering full-term, singleton infants and did not have missing values for prepregnancy weight, height, or GWG. The resulting sample represents approximately $79 \%$ of annual U.S. births.

Prepregnancy BMI was calculated using height and prepregnancy weight from the 2003 birth certificate or the PRAMS questionnaire. Prepregnancy BMI was categorized as underweight (BMI <18.5), normal weight (BMI = 18.5-24.9), overweight (BMI = 25.0-29.9), and obese (BMI $\geq 30.0)$. GWG was calculated by subtracting prepregnancy weight from delivery weight, and was categorized as inadequate, appropriate, or excessive if a woman gained below, within, or above the BMI-specific IOM recommendations, respectively. The IOM recommendations for GWG are 28-40 pounds for underweight women, 25-35 pounds for normal-weight women, 15-25 pounds for overweight women, and 11-20 pounds for obese women (1). Birth certificate and weighted PRAMS data were used separately to estimate state-specific prevalence and combined to estimate overall prevalence of inadequate, appropriate, and excessive GWG. The rationale for combining the data sets was based on a comparison of birth certificate data with data from an earlier analysis of PRAMS data in 28 states (2), which resulted in nearly identical estimates of inadequate, appropriate, and excessive GWG. Because prepregnancy BMI

\footnotetext{
$\dagger$ Alaska, California, Colorado, Delaware, Florida, Georgia, Idaho, Illinois, Indiana, Iowa, Kansas, Kentucky, Louisiana, Maryland, Massachusetts, Michigan, Minnesota, Mississippi, Missouri, Montana, Nebraska, Nevada, New Hampshire, New Mexico, New York, North Carolina, North Dakota, Ohio, Oklahoma, Oregon, Pennsylvania, South Carolina, South Dakota, Tennessee, Texas, Utah, Vermont, Virginia, Washington, Wisconsin, Wyoming.

$\S$ Arkansas, Hawaii, Maine, New Jersey, Rhode Island.

Data are unavailable for states that do not participate in PRAMS, do not reach the $65 \%$ response-rate threshold, or do not approve the analysis.

** Additional information available at http://www.cdc.gov/prams.
} 


\section{Summary}

What is already known on this topic?

The amount of weight a woman gains during pregnancy, known as gestational weight gain (GWG), has important maternal and infant health implications. A recent study estimated that $68 \%$ of women had GWG outside Institute of Medicine guidelines, including both inadequate (below recommendations) and excessive (above recommendations) weight gain. However, little is known about state-specific prevalence of inadequate and excessive GWG.

What is added by this report?

Overall, $32.1 \%$ of women had appropriate (within recommendations) GWG. Prevalence of inadequate GWG ranged by state from $12.6 \%-25.5 \%$; in 20 states and New York City, $\geq 20 \%$ of women had inadequate weight gain. Prevalence of excessive GWG ranged by state from $38.2 \%-54.7 \%$; in 17 states, $\geq 50 \%$ of women had excessive GWG. Stratification by prepregnancy BMI category indicated overweight and obese women had the highest prevalence of excessive GWG in nearly every state.

What are the implications for public health practice?

Interventions that might promote appropriate GWG combine several strategies, including calorie goals, physical activity, routine self-monitoring of weight, and frequent provider contact.

is an important determinant of GWG $(1,2)$, prevalences of inadequate, appropriate, and excessive GWG were stratified by prepregnancy BMI category. Stratified, state-specific prevalences standardized by race/ethnicity and age were also estimated.

The overall prevalence of appropriate GWG was 32.1\%, whereas the prevalence of inadequate GWG was $20.4 \%$ and the prevalence of excessive GWG was $47.5 \%$ (Table 1). States varied in prevalence of inadequate, appropriate, and excessive GWG. Inadequate GWG ranged from $12.6 \%$ in Rhode Island to $25.5 \%$ in Georgia; appropriate GWG ranged from $26.2 \%$ in Alaska to $39.0 \%$ in New Jersey; and excessive GWG ranged from $38.2 \%$ in New Jersey to $54.7 \%$ in Missouri. The prevalence of inadequate GWG was $\geq 20 \%$ in 20 states and New York City (Figure 1) and the prevalence of excessive GWG was $\geq 50 \%$ in 17 states (Figure 2).

Stratified by prepregnancy BMI, the prevalence of inadequate GWG was $32.2 \%$ for underweight, $23.6 \%$ for normal weight, $12.6 \%$ for overweight, and $20.6 \%$ for obese women. The prevalence of excessive GWG was $23.5 \%$ for underweight, $37.6 \%$ for normal weight, $61.6 \%$ for overweight, and $55.8 \%$ for obese women (Table 2). Although the prevalence of inadequate and excessive GWG within each prepregnancy BMI category varied by state, overweight women had the highest prevalence of excessive GWG in nearly every state. Variation by state persisted after standardization by race/ethnicity and age.
TABLE 1. State-specific prevalence of inadequate, appropriate, and excessive gestational weight gain* - 46 States, New York City, and District of Columbia, 2012 and $2013^{\dagger}$

\begin{tabular}{|c|c|c|c|}
\hline \multirow[b]{2}{*}{ Location } & \multicolumn{3}{|c|}{ Gestational weight gain } \\
\hline & $\begin{array}{c}\text { Inadequate } \\
\text { No. (\%) }\end{array}$ & $\begin{array}{c}\text { Appropriate } \\
\text { No. (\%) }\end{array}$ & $\begin{array}{c}\text { Excessive } \\
\text { No. (\%) }\end{array}$ \\
\hline Alaska & $1,770(19.6)$ & $2,369(26.2)$ & $4,896(54.2)$ \\
\hline Arkansas $§$ & $4,974(17.2)$ & $10,974(38.0)$ & $12,918(44.8)$ \\
\hline California & $89,026(21.4)$ & $142,928(34.3)$ & $184,910(44.4)$ \\
\hline Colorado & $12,804(22.7)$ & $19,291(34.3)$ & $24,230(43.0)$ \\
\hline Delaware & $1,800(19.2)$ & $2,722(29.0)$ & $4,850(51.8)$ \\
\hline District of Columbia & $1,316(17.8)$ & $2,600(35.1)$ & $3,491(47.1)$ \\
\hline Florida & $36,208(20.4)$ & $55,701(31.3)$ & $86,042(48.4)$ \\
\hline Georgia & $23,571(25.5)$ & $27,445(29.7)$ & $41,287(44.7)$ \\
\hline Hawaii ${ }^{\S}$ & $3,411(22.0)$ & $5,809(37.5)$ & $6,276(40.5)$ \\
\hline Idaho & $3,458(17.5)$ & $6,586(33.2)$ & $9,768(49.3)$ \\
\hline Illinois & $27,448(20.8)$ & $42,849(32.5)$ & $61,491(46.7)$ \\
\hline Indiana & $13,867(19.1)$ & $22,224(30.7)$ & $36,410(50.2)$ \\
\hline lowa & $5,615(16.3)$ & $10,059(29.1)$ & $18,871(54.6)$ \\
\hline Kansas & 6,597 (19.2) & $11,151(32.4)$ & $16,663(48.4)$ \\
\hline Kentucky & $9,848(20.7)$ & $14,026(29.4)$ & 23,767 (49.9) \\
\hline Louisiana & $11,474(22.0)$ & 15,569 (29.9) & $25,075(48.1)$ \\
\hline Maine ${ }^{\S}$ & $2,518(22.2)$ & 3,783 (33.4) & $5,033(44.4)$ \\
\hline Maryland & $13,109(22.1)$ & $17,072(28.8)$ & $29,073(49.1)$ \\
\hline Massachusetts & 9,956 (17.4) & 19,128 (33.3) & 28,305 (49.3) \\
\hline Michigan & $18,318(19.2)$ & 29,265 (30.6) & $48,092(50.3)$ \\
\hline Minnesota & $12,624(20.9)$ & $20,160(33.4)$ & $27,551(45.7)$ \\
\hline Mississippi & $6,958(21.5)$ & 9,519 (29.4) & $15,952(49.2)$ \\
\hline Missouri & 10,899 (17.3) & $17,614(28.0)$ & $34,378(54.7)$ \\
\hline Montana & $2,010(19.0)$ & 3,343 (31.7) & $5,211(49.3)$ \\
\hline Nebraska & $4,140(18.2)$ & $6,689(29.5)$ & $11,885(52.3)$ \\
\hline Nevada & $5,595(18.6)$ & $9,095(30.3)$ & $15,378(51.1)$ \\
\hline New Hampshire & $1,712(16.8)$ & $3,140(30.8)$ & $5,350(52.4)$ \\
\hline New Jersey ${ }^{\S}$ & $17,992(22.8)$ & $30,859(39.0)$ & $30,187(38.2)$ \\
\hline New Mexico & 4,104 (18.6) & $7,131(32.3)$ & $10,849(49.1)$ \\
\hline New York & $20,482(20.5)$ & $33,010(33.0)$ & $46,527(46.5)$ \\
\hline New York City & $22,329(21.8)$ & $37,060(36.2)$ & $42,945(42.0)$ \\
\hline North Carolina & 20,226 (19.9) & $30,831(30.4)$ & $50,455(49.7)$ \\
\hline North Dakota & 1,884 (20.3) & 2,833 (30.6) & 4,549 (49.1) \\
\hline Ohio & $20,832(18.6)$ & $31,868(28.5)$ & $59,092(52.9)$ \\
\hline Oklahoma & 9,631 (21.4) & $12,860(28.5)$ & $22,564(50.1)$ \\
\hline Oregon & $6,875(17.7)$ & $12,343(31.7)$ & $19,702(50.6)$ \\
\hline Pennsylvania & $19,820(18.9)$ & 31,359 (29.9) & $53,844(51.3)$ \\
\hline Rhode Island ${ }^{\S}$ & $970(12.6)$ & 2,792 (36.3) & $3,940(51.2)$ \\
\hline South Carolina & $10,345(21.5)$ & $14,469(30.1)$ & $23,246(48.4)$ \\
\hline South Dakota & 1,924 (18.0) & 3,142 (29.4) & $5,631(52.6)$ \\
\hline Tennessee & $12,269(18.6)$ & $19,180(29.0)$ & $34,587(52.4)$ \\
\hline Texas & $69,056(20.4)$ & $111,958(33.1)$ & $157,578(46.5)$ \\
\hline Utah & 8,087 (18.1) & 15,811 (35.3) & $20,838(46.6)$ \\
\hline Vermont & $1,013(19.2)$ & 1,679 (31.9) & $2,580(48.9)$ \\
\hline Virginia & $11,578(17.7)$ & $22,398(34.2)$ & $31,569(48.2)$ \\
\hline Washington & $15,351(21.3)$ & 23,391 (32.4) & $33,503(46.4)$ \\
\hline Wisconsin & $14,354(24.9)$ & $16,612(28.8)$ & $26,793(46.4)$ \\
\hline Wyoming & $1,109(16.8)$ & $2,004(30.3)$ & $3,495(52.9)$ \\
\hline PRAMS jurisdictions ${ }^{\S}$ & $29,865(21.0)$ & $54,217(38.1)$ & $58,352(41.0)$ \\
\hline $\mathrm{BC}$ jurisdictions & $601,392(20.4)$ & $940,484(31.8)$ & $1,413,273(47.8)$ \\
\hline Overall & $631,257(20.4)$ & $994,701(32.1)$ & $1,471,625(47.5)$ \\
\hline
\end{tabular}

Abbreviations: $\mathrm{BC}=$ birth certificate; PRAMS = Pregnancy Risk Assessment Monitoring System.

* Gestational weight gain below (inadequate), within (appropriate), and above (excessive) Institute of Medicine recommendations, which are based on prepregnancy body mass index (BMI): 28-40 pounds for underweight women (BMl <18.5), 25-35 pounds for normal-weight women $(\mathrm{BMI}=18.5-24.9), 15-25$ pounds for overweight women (BMI 25.0-29.9), and 11-20 pounds for obese women (BMI $\geq 30.0$ ).

† Based on analysis of data from 2012 PRAMS for five states and 2013 birth certificate for 41 states, New York City, and District of Columbia.

$\S$ Data are from PRAMS and are presented as weighted frequencies and percent. 
FIGURE 1. Prevalence of inadequate gestational weight gain (GWG)* - 46 states, New York City, and District of Columbia, 2012-2013

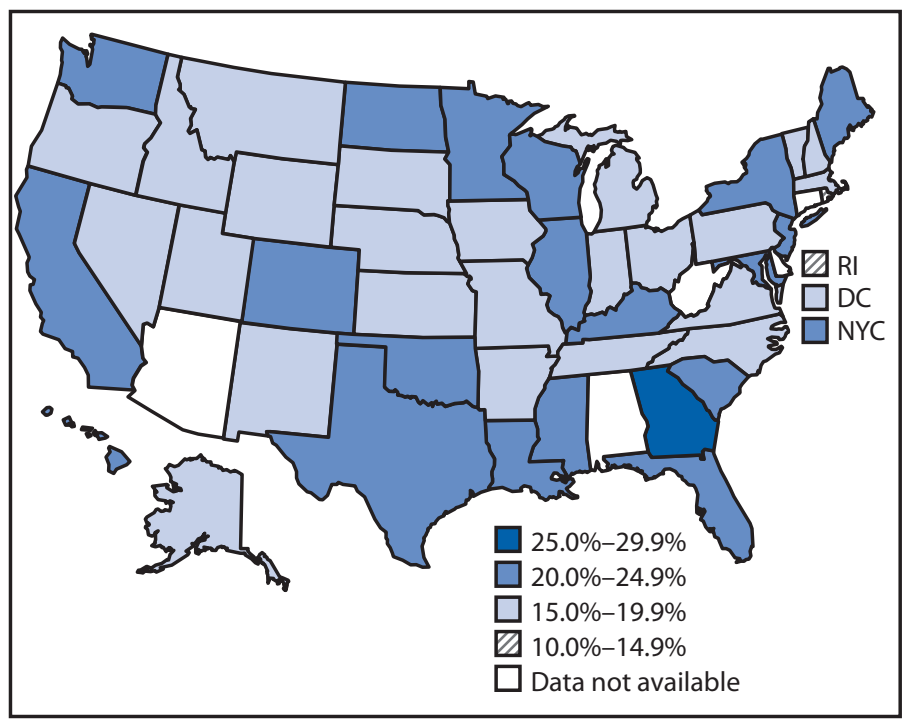

Abbreviations: DC = District of Columbia; NYC = New York City; RI = Rhode Island Sources: 2012 Pregnancy Risk Assessment Monitoring Systems for five states (Arkansas, Hawaii, Maine, New Jersey, Rhode Island) and 2013 birth certificates for 41 states, New York City, and District of Columbia.

* Gestational weight gain below Institute of Medicine recommendations, which are based on prepregnancy body mass index (BMI): 28-40 pounds for underweight women (BMI <18.5), 25-35 pounds for normal-weight women $(\mathrm{BMI}=18.5-24.9), 15-25$ pounds for overweight women $(\mathrm{BMI}=25.0-29.9)$, and $11-20$ pounds for obese women (BMI $\geq 30.0$ ).

\section{Discussion}

Gestational weight gain outside the IOM recommendations has important short- and long-term health consequences for mothers and infants. Whereas, inadequate GWG increases the risk for low birthweight; excessive GWG increases the risk for macrosomia, postpartum weight retention, future maternal obesity, and possibly future childhood obesity (1). Among women from 46 states, New York City, and DC who delivered a full-term, singleton infant, only one third had appropriate GWG, whereas $20 \%$ had inadequate GWG and approximately half had excessive GWG. Excessive GWG was more prevalent than inadequate or appropriate GWG in every state; in 17 states, the prevalence of excessive GWG was $\geq 50 \%$. Other studies have reported similar findings (2) and indicate that during the past decade, the prevalence of excessive GWG has increased and prevalence of inadequate GWG has remained stable (3). These findings indicate that effective interventions during pregnancy, in addition to routine prenatal care, are needed to promote appropriate GWG.

The American College of Obstetricians and Gynecologists recommends that clinicians calculate a woman's prepregnancy BMI at the first prenatal care visit, educate her on the importance of appropriate GWG goals, and counsel her on appropriate dietary and physical activity behaviors to achieve these
FIGURE 2. Prevalence of excessive gestational weight gain (GWG)* - 46 states, New York City, and District of Columbia, 2012-2013

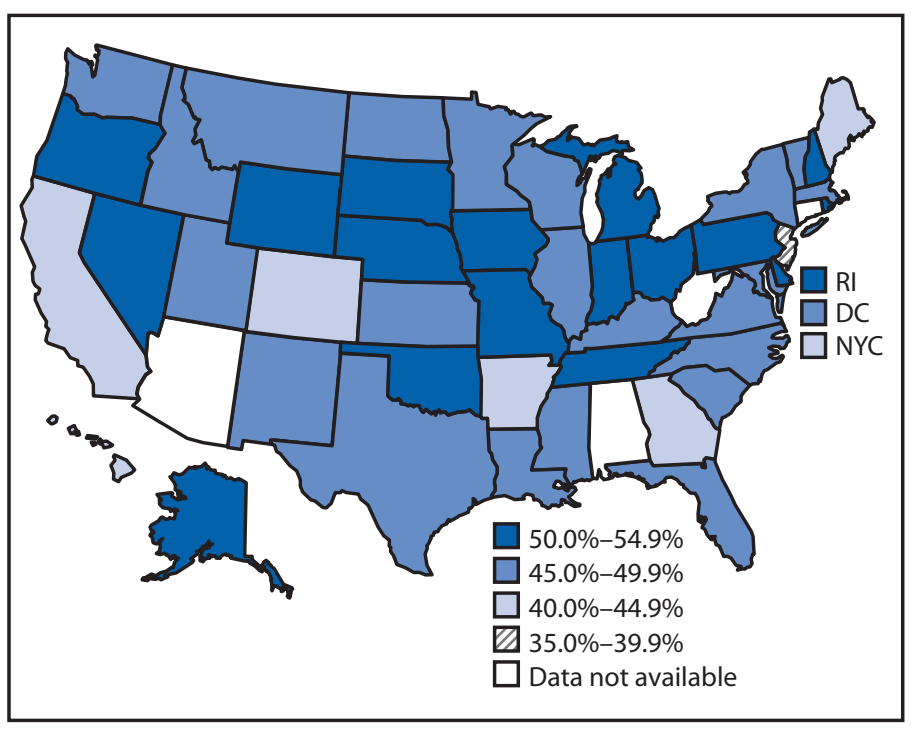

Abbreviations: DC $=$ District of Columbia; NYC $=$ New York City; RI = Rhode Island Sources: 2012 Pregnancy Risk Assessment Monitoring Systems for five states (Arkansas, Hawaii, Maine, New Jersey, Rhode Island) and 2013 birth certificates for 41 states, New York City, and District of Columbia.

* Gestational weight gain above Institute of Medicine recommendations, which are based on prepregnancy body mass index (BMI): 28-40 pounds for underweight women (BMI <18.5), 25-35 pounds for normal-weight women $(\mathrm{BMI}=18.5-24.9), 15-25$ pounds for overweight women $(\mathrm{BMI}=25.0-29.9)$, and $11-20$ pounds for obese women (BMI $\geq 30.0)$.

goals. Education, counseling, and monitoring of GWG should continue throughout pregnancy (4). The IOM developed an evidence-based toolkit that includes educational materials for clinicians and women and a BMI-specific weight gain tracker that can be used to monitor and compare GWG with recommended ranges throughout pregnancy. ${ }^{\dagger \dagger}$

Interventions that might promote appropriate GWG combine several strategies, including dietary goals, physical activity, routine self-monitoring of weight, and frequent provider contact. Most women need to consume an additional 340-450 calories per day only during the second and third trimesters to support the metabolic demands of pregnancy (1); dietary goals might be helpful to meet these additional energy requirements $(5,6)$. Physical activity, when combined with dietary goals, has been found to be an effective strategy in preventing excessive GWG (5,6). Pregnant women should engage in 150 minutes per week of moderate-intensity physical activity, such as brisk walking (7). Routine self-monitoring of weight gain should begin early in pregnancy and continue frequently between prenatal care visits so that signals of inadequate or excessive GWG can be identified when small, corrective steps can be taken (5). Notably, excessive GWG early in pregnancy strongly predicts

${ }^{\dagger \dagger}$ Additional information available at http://iom.nationalacademies.org/AboutIOM/Leadership-Staff/IOM-Staff-Leadership-Boards/Food-and-NutritionBoard/HealthyPregnancy.aspx. 
TABLE 2. State-specific prevalence of inadequate, appropriate, and excessive gestational weight gain by prepregnancy body mass index

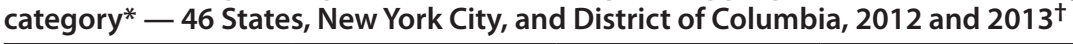

\begin{tabular}{|c|c|c|c|c|c|c|}
\hline \multirow[b]{2}{*}{ State } & \multicolumn{3}{|c|}{ Underweight ( $n=116,287)$} & \multicolumn{3}{|c|}{ Normal weight ( $n=1,460,476)$} \\
\hline & $\begin{array}{c}\text { Inadequate } \\
\text { No. (\%) }\end{array}$ & $\begin{array}{c}\text { Appropriate } \\
\text { No. (\%) }\end{array}$ & $\begin{array}{c}\text { Excessive } \\
\text { No. (\%) }\end{array}$ & $\begin{array}{c}\text { Inadequate } \\
\text { No. (\%) }\end{array}$ & $\begin{array}{c}\text { Appropriate } \\
\text { No. (\%) }\end{array}$ & $\begin{array}{c}\text { Excessive } \\
\text { No. (\%) }\end{array}$ \\
\hline Alaska & $58(24.4)$ & $113(47.5)$ & $67(28.2)$ & 758 (17.9) & $1,427(33.7)$ & $2,048(48.4)$ \\
\hline Arkansas $§$ & ๆ & ๆ & ๆ & $3,013(23.2)$ & $5,759(44.4)$ & $4,199(32.4)$ \\
\hline California & $5,350(33.8)$ & $7,155(45.3)$ & $3,308(20.9)$ & $51,251(25.6)$ & 80,041 (39.9) & $69,182(34.5)$ \\
\hline Colorado & 771 (37.1) & 902 (43.4) & 407 (19.6) & 7,537 (26.3) & $11,517(40.2)$ & 9,599 (33.5) \\
\hline Delaware & $94(30.5)$ & $135(43.8)$ & $79(25.7)$ & $872(21.0)$ & $1,500(36.2)$ & $1,775(42.8)$ \\
\hline District of Columbia & 89 (29.6) & $142(47.2)$ & $70(23.3)$ & $841(21.2)$ & $1,722(43.4)$ & $1,407(35.4)$ \\
\hline Florida & $2,465(30.8)$ & $3,394(42.3)$ & $2,157(26.9)$ & $20,336(23.8)$ & $31,173(36.5)$ & $33,837(39.7)$ \\
\hline Georgia & $1,155(32.5)$ & $1,581(44.5)$ & $818(23.0)$ & $10,012(25.5)$ & $14,394(36.7)$ & $14,855(37.8)$ \\
\hline Hawaii§ & ๆ & १ & १ & $2,557(27.3)$ & 4,049 (43.2) & 2,771 (29.6) \\
\hline Idaho & 201 (30.6) & $306(46.7)$ & $149(22.7)$ & 1,906 (19.6) & $3,925(40.3)$ & $3,915(40.2)$ \\
\hline Illinois & $1,440(33.6)$ & $1,921(44.8)$ & $928(21.6)$ & $14,834(25.0)$ & $23,260(39.1)$ & $21,338(35.9)$ \\
\hline Indiana & $796(30.1)$ & $1,176(44.5)$ & $672(25.4)$ & $7,319(23.1)$ & $11,745(37.1)$ & $12,602(39.8)$ \\
\hline lowa & $297(28.6)$ & 487 (46.9) & $254(24.5)$ & $2,802(17.8)$ & $5,933(37.7)$ & $6,991(44.5)$ \\
\hline Kansas & $375(33.0)$ & $495(43.5)$ & $267(23.5)$ & $3,563(22.4)$ & $6,416(40.4)$ & $5,920(37.2)$ \\
\hline Kentucky & $621(29.7)$ & $937(44.8)$ & $532(25.5)$ & $4,541(22.3)$ & $7,321(36.0)$ & $8,471(41.7)$ \\
\hline Louisiana & $730(34.2)$ & $911(42.7)$ & $493(23.1)$ & $5,740(25.2)$ & $8,281(36.3)$ & $8,791(38.5)$ \\
\hline Maine $e^{\S}$ & ก & ก & व & $1,459(27.3)$ & $2,075(38.8)$ & $1,810(33.9)$ \\
\hline Maryland & 632 (32.6) & $855(44.1)$ & $453(23.4)$ & $6,071(22.0)$ & $10,424(37.7)$ & $11,148(40.3)$ \\
\hline Massachusetts & $624(29.6)$ & $950(45.1)$ & $533(25.3)$ & $5,878(19.4)$ & $12,831(42.4)$ & $11,557(38.2)$ \\
\hline Michigan & $952(31.3)$ & $1,333(43.8)$ & $760(25.0)$ & $9,841(23.1)$ & $15,837(37.2)$ & $16,844(39.6)$ \\
\hline Minnesota & $506(37.0)$ & $624(45.6)$ & $238(17.4)$ & $6,907(25.0)$ & $11,340(41.0)$ & $9,396(34.0)$ \\
\hline Mississippi & 468 (31.4) & 653 (43.8) & $369(24.8)$ & $3,408(26.2)$ & 4,459 (34.3) & $5,144(39.5)$ \\
\hline Missouri & $664(26.2)$ & 1,099 (43.4) & $772(30.5)$ & $5,397(18.3)$ & $10,537(35.6)$ & $13,635(46.1)$ \\
\hline Montana & $116(31.5)$ & $174(47.3)$ & $78(21.2)$ & $1,116(21.5)$ & 1,985 (38.3) & $2,083(40.2)$ \\
\hline Nebraska & $224(31.3)$ & $306(42.8)$ & $185(25.9)$ & $2,126(19.7)$ & $4,041(37.4)$ & 4,641 (42.9) \\
\hline Nevada & $345(26.3)$ & $615(47.0)$ & $350(26.7)$ & $2,949(20.4)$ & $5,314(36.7)$ & $6,226(43.0)$ \\
\hline New Hampshire & $86(27.6)$ & 137 (43.9) & $89(28.5)$ & $990(19.7)$ & 1,879 (37.4) & $2,158(42.9)$ \\
\hline New Jersey ${ }^{\S}$ & ก & ก & १ & $12,379(28.6)$ & $19,079(44.0)$ & $11,872(27.4)$ \\
\hline New Mexico & 269 (30.9) & 380 (43.6) & $222(25.5)$ & $2,274(23.0)$ & 3,746 (37.8) & $3,882(39.2)$ \\
\hline New York & $1,083(35.2)$ & $1,340(43.5)$ & 657 (21.3) & $11,693(25.2)$ & 18,339 (39.6) & $16,333(35.2)$ \\
\hline New York City & 1,899 (34.7) & $2,549(46.5)$ & 1,031 (18.8) & $14,910(27.2)$ & $22,447(41.0)$ & $17,443(31.8)$ \\
\hline North Carolina & $1,288(32.0)$ & $1,731(43.0)$ & $1,005(25.0)$ & $10,740(23.3)$ & $16,980(36.8)$ & $18,481(40.0)$ \\
\hline North Dakota & $55(26.8)$ & $99(48.3)$ & $51(24.9)$ & $930(23.5)$ & $1,516(38.4)$ & $1,507(38.1)$ \\
\hline Ohio & $1,251(28.6)$ & $1,939(44.4)$ & $1,179(27.0)$ & $10,143(19.5)$ & $18,762(36.0)$ & $23,147(44.5)$ \\
\hline Oklahoma & 579 (29.8) & 795 (40.9) & $569(29.3)$ & $4,516(22.8)$ & 6,956 (35.2) & $8,305(42.0)$ \\
\hline Oregon & $339(27.1)$ & $581(46.5)$ & $330(26.4)$ & $3,828(20.2)$ & $7,341(38.8)$ & $7,758(41.0)$ \\
\hline Pennsylvania & $1,146(29.0)$ & $1,801(45.5)$ & $1,010(25.5)$ & $10,353(20.1)$ & $19,394(37.7)$ & $21,757(42.2)$ \\
\hline Rhode Island ${ }^{\S}$ & ी & १ & १ & $632(15.7)$ & $1,788(44.5)$ & $1,595(39.7)$ \\
\hline South Carolina & $584(31.7)$ & $808(43.8)$ & $453(24.6)$ & $4,925(24.1)$ & $7,529(36.8)$ & $8,008(39.1)$ \\
\hline South Dakota & 87 (26.7) & $158(48.5)$ & $81(24.9)$ & 982 (19.5) & 1,869 (37.0) & $2,199(43.5)$ \\
\hline Tennessee & $824(28.1)$ & 1,259 (42.9) & $850(29.0)$ & 6,367 (20.7) & $11,164(36.4)$ & $13,174(42.9)$ \\
\hline Texas & 4,251 (32.9) & $5,641(43.6)$ & $3,043(23.5)$ & $39,514(25.1)$ & $62,032(39.4)$ & $55,859(35.5)$ \\
\hline Utah & $614(31.3)$ & $963(49.1)$ & 385 (19.6) & $4,731(19.5)$ & $10,348(42.6)$ & 9,201 (37.9) \\
\hline Vermont & $58(37.7)$ & $68(44.2)$ & ก & $532(20.9)$ & 1,061 (41.6) & 955 (37.5) \\
\hline Virginia & 792 (31.8) & $1,135(45.5)$ & $567(22.7)$ & $6,688(20.9)$ & $13,441(42.0)$ & $11,911(37.2)$ \\
\hline Washington & $637(30.1)$ & $954(45.1)$ & $526(24.9)$ & $7,774(23.4)$ & $13,231(39.8)$ & $12,272(36.9)$ \\
\hline Wisconsin & $447(32.6)$ & $616(44.9)$ & $310(22.6)$ & $5,537(22.2)$ & 9,453 (37.9) & $9,973(40.0)$ \\
\hline Wyoming & $74(30.3)$ & $94(38.5)$ & $76(31.2)$ & $649(19.3)$ & $1,279(38.0)$ & $1,439(42.7)$ \\
\hline PRAMS jurisdictions $§$ & $2,068(39.5)$ & $2,186(41.7)$ & $984(18.8)$ & $20,041(26.7)$ & $32,750(43.6)$ & $22,248(29.6)$ \\
\hline $\mathrm{BC}$ jurisdictions & $35,336(31.8)$ & $49,312(44.4)$ & $26,401(23.8)$ & $324,081(23.4)$ & $534,190(38.6)$ & $527,167(38.1)$ \\
\hline Overall & $37,404(32.2)$ & $51,498(44.3)$ & $27,385(23.5)$ & $344,122(23.6)$ & $566,940(38.8)$ & 549,415 (37.6) \\
\hline
\end{tabular}

See table footnotes on next page. 
TABLE 2. (Continued) State-specific prevalence of inadequate, appropriate, and excessive gestational weight gain by prepregnancy body mass index category* -46 States, New York City, and District of Columbia, 2012 and $2013^{\dagger}$

\begin{tabular}{|c|c|c|c|c|c|c|}
\hline \multirow[b]{2}{*}{ State } & \multicolumn{3}{|c|}{ Overweight $(n=793,191)$} & \multicolumn{3}{|c|}{ Obese $(n=727,628)$} \\
\hline & $\begin{array}{c}\text { Inadequate } \\
\text { No. (\%) }\end{array}$ & $\begin{array}{c}\text { Appropriate } \\
\text { No. (\%) }\end{array}$ & $\begin{array}{c}\text { Excessive } \\
\text { No. (\%) }\end{array}$ & $\begin{array}{l}\text { Inadequate } \\
\text { No. (\%) }\end{array}$ & $\begin{array}{c}\text { Appropriate } \\
\text { No. (\%) }\end{array}$ & $\begin{array}{l}\text { Excessive } \\
\text { No. (\%) }\end{array}$ \\
\hline Alaska & $364(15.6)$ & $436(18.7)$ & $1,533(65.7)$ & $590(26.5)$ & $393(17.6)$ & $1,248(55.9)$ \\
\hline Arkansas $§$ & 9 & $2,209(29.5)$ & $4,761(63.6)$ & 9 & $2,480(32.7)$ & $3,688(48.6)$ \\
\hline California & $14,395(13.1)$ & $32,108(29.3)$ & $63,039(57.6)$ & $18,030(19.8)$ & $23,624(26.0)$ & $49,381(54.2)$ \\
\hline Colorado & 2,146 (14.9) & $3,965(27.5)$ & $8,300(57.6)$ & $2,350(21.0)$ & 2,907 (26.0) & $5,924(53.0)$ \\
\hline Delaware & $316(12.7)$ & $562(22.6)$ & $1,612(64.7)$ & $518(21.3)$ & 525 (21.6) & $1,384(57.0)$ \\
\hline District of Columbia & $161(9.8)$ & $396(24.1)$ & $1,088(66.1)$ & $225(15.1)$ & $340(22.8)$ & $926(62.1)$ \\
\hline Florida & $5,944(13.0)$ & $11,826(25.8)$ & $28,037(61.2)$ & $7,463(19.2)$ & $9,308(24.0)$ & $22,011(56.8)$ \\
\hline Georgia & 4,861 (20.2) & $5,722(23.7)$ & $13,547(56.1)$ & $7,543(29.8)$ & $5,748(22.7)$ & $12,067(47.6)$ \\
\hline Hawaii $\$$ & व & $860(29.0)$ & $1,875(63.2)$ & व & $682(26.8)$ & $1,508(59.3)$ \\
\hline Idaho & $511(10.1)$ & $1,249(24.8)$ & $3,281(65.1)$ & $840(19.2)$ & $1,106(25.3)$ & $2,423(55.5)$ \\
\hline Illinois & $4,480(12.6)$ & $9,722(27.4)$ & $21,257(60.0)$ & $6,694(20.5)$ & $7,946(24.4)$ & $17,968(55.1)$ \\
\hline Indiana & $2,082(11.1)$ & 4,771 (25.4) & 11,959 (63.6) & $3,670(18.9)$ & 4,532 (23.4) & $11,177(57.7)$ \\
\hline lowa & $750(8.4)$ & $1,837(20.5)$ & 6,366 (71.1) & $1,766(20.0)$ & $1,802(20.4)$ & $5,260(59.6)$ \\
\hline Kansas & $997(11.3)$ & $2,221(25.3)$ & $5,571(63.4)$ & $1,662(19.4)$ & $2,019(23.5)$ & $4,905(57.1)$ \\
\hline Kentucky & $1,640(13.6)$ & $2,808(23.4)$ & $7,579(63.0)$ & $3,046(23.1)$ & $2,960(22.4)$ & $7,185(54.5)$ \\
\hline Louisiana & $1,815(13.9)$ & $3,115(23.9)$ & $8,118(62.2)$ & $3,189(22.6)$ & $3,262(23.1)$ & $7,673(54.3)$ \\
\hline Maine ${ }^{\S}$ & व & $853(28.7)$ & $1,740(58.5)$ & ก & 9 & $1,394(54.8)$ \\
\hline Maryland & $2,579(16.6)$ & $3,220(20.8)$ & $9,718(62.6)$ & $3,827(27.0)$ & $2,573(18.2)$ & $7,754(54.8)$ \\
\hline Massachusetts & $1,518(10.6)$ & $3,167(22.1)$ & $9,640(67.3)$ & $1,936(18.1)$ & $2,180(20.4)$ & $6,575(61.5)$ \\
\hline Michigan & $2,757(11.2)$ & $6,200(25.1)$ & 15,766 (63.8) & 4,768 (18.8) & $5,895(23.2)$ & $14,722(58.0)$ \\
\hline Minnesota & $2,129(13.0)$ & 4,397 (26.9) & $9,817(60.1)$ & $3,082(20.6)$ & $3,799(25.4)$ & $8,100(54.1)$ \\
\hline Mississippi & $1,116(13.9)$ & $1,984(24.7)$ & $4,942(61.5)$ & $1,966(19.9)$ & $2,423(24.5)$ & $5,497(55.6)$ \\
\hline Missouri & $1,524(10.0)$ & $3,080(20.1)$ & $10,716(70.0)$ & $3,314(21.4)$ & $2,898(18.7)$ & $9,255(59.8)$ \\
\hline Montana & $292(10.8)$ & $643(23.8)$ & $1,771(65.5)$ & $486(21.1)$ & $541(23.5)$ & $1,279(55.5)$ \\
\hline Nebraska & 639 (10.9) & $1,236(21.0)$ & $3,999(68.1)$ & $1,151(21.7)$ & $1,106(20.8)$ & $3,060(57.6)$ \\
\hline Nevada & $968(12.7)$ & $1,780(23.3)$ & $4,899(64.1)$ & $1,333(20.1)$ & $1,386(20.9)$ & $3,903(58.9)$ \\
\hline New Hampshire & 202 (7.9) & $584(23.0)$ & 1,757 (69.1) & 434 (18.7) & $540(23.3)$ & $1,346(58.0)$ \\
\hline New Jersey ${ }^{\S}$ & ก & $6,114(31.7)$ & $11,424(59.3)$ & $2,360(17.6)$ & ก & $6,458(48.2)$ \\
\hline New Mexico & $668(11.4)$ & $1,565(26.8)$ & $3,613(61.8)$ & $893(16.3)$ & $1,440(26.4)$ & $3,132(57.3)$ \\
\hline New York & $3,143(11.8)$ & $7,439(28.0)$ & $15,983(60.2)$ & 4,563 (19.0) & $5,892(24.5)$ & $13,554(56.5)$ \\
\hline New York City & $3,142(12.6)$ & $7,775(31.0)$ & $14,128(56.4)$ & $2,378(14.0)$ & $4,289(25.2)$ & $10,343(60.8)$ \\
\hline North Carolina & $3,060(11.8)$ & 6,396 (24.8) & $16,378(63.4)$ & $5,138(20.2)$ & $5,724(22.5)$ & $14,591(57.3)$ \\
\hline North Dakota & 331 (13.2) & $600(23.9)$ & $1,583(63.0)$ & $568(21.9)$ & $618(23.8)$ & $1,408(54.3)$ \\
\hline Ohio & $3,097(11.2)$ & $5,716(20.7)$ & $18,858(68.2)$ & $6,341(22.9)$ & $5,451(19.7)$ & $15,908(57.4)$ \\
\hline Oklahoma & $1,740(15.3)$ & $2,611(22.9)$ & 7,044 (61.8) & $2,796(23.4)$ & $2,498(20.9)$ & $6,646(55.7)$ \\
\hline Oregon & $990(10.2)$ & $2,303(23.8)$ & $6,395(66.0)$ & $1,718(19.0)$ & $2,118(23.4)$ & $5,219(57.6)$ \\
\hline Pennsylvania & $3,013(11.7)$ & $5,513(21.5)$ & $17,173(66.8)$ & $5,308(22.2)$ & 4,651 (19.5) & $13,904(58.3)$ \\
\hline Rhode Island ${ }^{\S}$ & व & $433(23.5)$ & $1,292(70.1)$ & $110(7.2)$ & ก & $981(64.3)$ \\
\hline South Carolina & $1,731(14.3)$ & $2,955(24.4)$ & $7,411(61.3)$ & $3,105(22.7)$ & 3,177 (23.3) & $7,374(54.0)$ \\
\hline South Dakota & $303(10.9)$ & $600(21.6)$ & $1,872(67.5)$ & $552(21.7)$ & $515(20.2)$ & $1,479(58.1)$ \\
\hline Tennessee & $1,846(11.5)$ & $3,546(22.0)$ & 10,715 (66.5) & $3,232(19.8)$ & 3,211 (19.7) & $9,848(60.5)$ \\
\hline Texas & $10,784(12.3)$ & $24,372(27.8)$ & $52,461(59.9)$ & $14,507(18.0)$ & $19,913(24.7)$ & $46,215(57.3)$ \\
\hline Utah & $1,029(10.0)$ & $2,530(24.7)$ & $6,688(65.3)$ & $1,713(20.8)$ & $1,970(23.9)$ & $4,564(55.3)$ \\
\hline Vermont & $143(11.1)$ & $270(21.0)$ & $872(67.9)$ & $280(21.8)$ & $280(21.8)$ & $725(56.4)$ \\
\hline Virginia & 1,611 (9.7) & $4,281(25.6)$ & $10,808(64.7)$ & $2,487(17.4)$ & $3,541(24.7)$ & $8,283(57.9)$ \\
\hline Washington & $2,646(13.9)$ & $4,946(25.9)$ & $11,483(60.2)$ & 4,294 (24.2) & $4,260(24.0)$ & $9,222(51.9)$ \\
\hline Wisconsin & $3,101(20.2)$ & $3,335(21.7)$ & $8,946(58.2)$ & $5,269(32.9)$ & $3,208(20.0)$ & $7,564(47.2)$ \\
\hline Wyoming & $130(8.3)$ & $326(20.7)$ & $1,118(71.0)$ & $256(18.0)$ & $305(21.4)$ & $862(60.6)$ \\
\hline PRAMS jurisdictions $\S$ & $2,987(8.6)$ & $10,469(30.3)$ & $21,092(61.1)$ & $4,769(17.3)$ & $8,811(31.9)$ & $14,029(50.8)$ \\
\hline BC jurisdictions & 96,694 (12.7) & $194,108(25.6)$ & $467,841(61.7)$ & $145,281(20.8)$ & $162,874(23.3)$ & $391,864(56.0)$ \\
\hline Overall & $99,681(12.6)$ & $204,577(25.9)$ & $488,933(61.6)$ & $150,050(20.6)$ & $171,685(23.6)$ & $405,893(55.8)$ \\
\hline
\end{tabular}

Abbreviations: $\mathrm{BC}=$ birth certificate; PRAMS = Pregnancy Risk Assessment Monitoring System.

* Gestational weight gain below (inadequate) and above (excessive) Institute of Medicine recommendations, which are based on prepregnancy body mass index (BMI): 28-40 pounds for underweight women (BMI <18.5), 25-35 pounds for normal-weight women (BMI = 18.5-24.9), 15-25 pounds for overweight women (BMI 25.0-29.9), and 11-20 pounds for obese women (BMI $\geq 30.0)$.

† Based on data from the 2012 PRAMS for five states and 2013 birth certificate for 41 states, New York City, and District of Columbia.

$\S$ Data are from PRAMS and are presented as weighted frequencies and percent.

" Data suppressed because of small (<30) sample size. 
total excessive GWG (8), suggesting that women with early excessive GWG might need to be prioritized for interventions. Frequent, ongoing contact with health care providers beyond routine prenatal care, such as nurses or nutrition specialists, might also help women achieve appropriate GWG (5).

Prepregnancy BMI is an important determinant of inappropriate GWG: underweight and class II or III obesity (BMI $\geq 35-<40$ or BMI $\geq 40$, respectively) increase risk for inadequate GWG whereas overweight and any obesity increase risk for excessive GWG $(1,2)$. Within prepregnancy BMI categories, risk for inadequate and excessive GWG has been found to vary by maternal race/ethnicity and age (2). After adjustment for prepregnancy BMI and demographic characteristics associated with inappropriate GWG, state variation in prevalence of inadequate and excessive GWG persisted, suggesting that social, environmental, and policy determinants of GWG should be considered. Public health campaigns designed to raise awareness about GWG recommendations and alter social norms around diet and physical activity during pregnancy might be needed to effectively promote appropriate GWG (9). Some women might also believe that physical activity during pregnancy is risky (9); however, physical activity is safe and recommended for most pregnant women and might reduce some pregnancy-related complications $(7,10)$. Access to healthy foods, opportunities for physical activity, and expanded medical and nutrition services for pregnant women are plausible environmental and policy determinants of GWG; however, more studies are needed to evaluate these influences on inadequate or excessive GWG (1).

The findings in this report are subject to at least three limitations. First, weight data from the birth certificate were derived from medical records or self-reported and weight data from the PRAMS questionnaire were obtained approximately 4 months postpartum; consequently, prepregnancy BMI or GWG might be misclassified. Second, analyses were restricted to pregnancies resulting in full-term, singleton infants; thus, findings might not be applicable to all pregnancies. Finally, because nationally representative data are not available, two data sources with different sampling and variable ascertainment methodologies were used; this might affect some state-to-state comparisons and actual overall results. However, comparison of estimates of GWG using only birth certificate data from the current analysis with an analysis of PRAMS data from 28 states (2) found nearly identical inadequate, appropriate and excessive GWG prevalence estimates, suggesting that the two data sources are comparable in their aggregate prevalence estimates.
Fewer than one third of women had GWG within IOM recommendations. The high prevalence of excessive GWG, which varies by state and prepregnancy BMI, is of concern because excessive GWG increases the risk for macrosomia, postpartum weight retention, and obesity in mothers and possibly children. To improve maternal and child health, intensified, multifaceted strategies are important for increasing the proportion of women who achieve appropriate GWG.

\section{Acknowledgments}

PRAMS Working Group. List of members available at http://www. cdc.gov/prams/pdf/workinggroup_7-2012.pdf.

\footnotetext{
${ }^{1}$ Division of Reproductive Health, National Center for Chronic Disease Prevention and Health Promotion, CDC; ${ }^{2}$ Nutrition and Health Sciences Program, Laney Graduate School, Emory University, Atlanta, Georgia; ${ }^{3} \mathrm{Oak}$ Ridge Institute for Science Education Fellowship, U.S. Department of Energy.

Corresponding author: Andrea J. Sharma, ajsharma@cdc.gov, 770-488-5957.
}

\section{References}

1. Rasmussen KM, Yaktine AL, editors. Weight gain during pregnancy: reexamining the guidelines. Washington, DC: The National Academies Press; 2009.

2. Deputy NP, Sharma AJ, Kim SY, Hinkle SN. Prevalence and characteristics associated with gestational weight gain adequacy. Obstet Gynecol 2015;125:773-81.

3. Johnson JL, Farr SL, Dietz PM, Sharma AJ, Barfield WD, Robbins CL. Trends in gestational weight gain: the Pregnancy Risk Assessment Monitoring System, 2000-2009. Am J Obstet Gynecol 2015;212:806.e1-8.

4. American College of Obstetricians and Gynecologists. ACOG Committee opinion no. 548: weight gain during pregnancy. Obstet Gynecol 2013;121:210-2.

5. Phelan S, Jankovitz K, Hagobian T, Abrams B. Reducing excessive gestational weight gain: lessons from the weight control literature and avenues for future research. Womens Health (Lond Engl) 2011;7:641-61.

6. Muktabhant B, Lawrie TA, Lumbiganon P, Laopaiboon M. Diet or exercise, or both, for preventing excessive weight gain in pregnancy. Cochrane Database Syst Rev 2015;6:CD007145.

7. US Department of Health and Human Services. 2008 physical activity guidelines for Americans. Washington, DC: US Department of Health and Human Services; 2008. Available at http://health.gov/paguidelines/ pdf/paguide.pdf.

8. Knabl J, Riedel C, Gmach J, et al. Prediction of excessive gestational weight gain from week-specific cutoff values: a cohort study. J Perinatol 2014;34:351-6.

9. Kraschnewski JL, Chuang CH. "Eating for two": excessive gestational weight gain and the need to change social norms. Womens Health Issues 2014;24:e257-9.

10. American College of Obstetricians and Gynecologists. ACOG committee opinion no. 267: exercise during pregnancy and the postpartum period. Obstet Gynecol 2002;99:171-3. 


\title{
Vital Signs: Multistate Foodborne Outbreaks — United States, 2010-2014
}

\author{
Samuel J. Crowe, $\mathrm{PhD}^{1,2}$; Barbara E. Mahon, $\mathrm{MD}^{2}$; Antonio R. Vieira, $\mathrm{PhD}^{2}$; L. Hannah Gould, $\mathrm{PhD}^{2}$
}

On November 3, 2015 this report was posted as an MMWR Early Release on the MMWR website (http://www.cdc.gov/mmwr).

\section{Abstract}

Introduction: Millions of U.S. residents become ill from foodborne pathogens each year. Most foodborne outbreaks occur among small groups of persons in a localized area. However, because many foods are distributed widely and rapidly, and because detection methods have improved, outbreaks that occur in multiple states and that even span the entire country are being recognized with increasing frequency.

Methods: This report analyzes data from CDC's Foodborne Disease Outbreak Surveillance System to describe multistate foodborne outbreaks that occurred in the United States during 2010-2014.

Results: During this 5-year period, 120 multistate foodborne disease outbreaks (with identified pathogen and food or common setting) were reported to CDC. These multistate outbreaks accounted for 3\% $(120$ of 4,163) of all reported foodborne outbreaks, but were responsible for $11 \%(7,929$ of 71,747$)$ of illnesses, $34 \%(1,460$ of 4,247$)$ of hospitalizations, and 56\% (66 of 118) of deaths associated with foodborne outbreaks. Salmonella (63 outbreaks), Shiga toxin-producing E. coli (34), and Listeria monocytogenes (12) were the leading pathogens. Fruits (17), vegetable row crops (15), beef (13), sprouts (10), and seeded vegetables (nine) were the most commonly implicated foods. Traceback investigations to identify the food origin were conducted for 87 outbreaks, of which 55 led to a product recall. Imported foods were linked to 18 multistate outbreaks.

Conclusions: Multistate foodborne disease outbreaks account for a disproportionate number of outbreak-associated illnesses, hospitalizations, and deaths relative to their occurrence. Working together, food industries and public health departments and agencies can develop and implement more effective ways to identify and to trace contaminated foods linked to multistate outbreaks. Lessons learned during outbreak investigations can help improve food safety practices and regulations, and might prevent future outbreaks.

\section{Introduction}

Each year, millions of U.S. residents become ill from eating contaminated food (1). Some of these illnesses are associated with a recognized foodborne disease outbreak. Although most outbreaks occur locally, some are widely dispersed, affecting persons in more than one state, or even nationally.

This report characterizes the epidemiology of multistate foodborne disease outbreaks that occurred in the United States during 2010-2014 and describes how the food industries and local, state, and federal agencies collaborate to investigate outbreaks and use lessons learned to prevent future outbreaks.

\section{Methods}

Local, state, and federal public health officials submit reports on multistate foodborne disease outbreaks to CDC's Foodborne Disease Outbreak Surveillance System, which is part of CDC's National Outbreak Reporting System. Foodborne outbreaks are defined as two or more cases of a similar illness caused by ingesting the same food. Multistate foodborne disease outbreaks are defined as foodborne outbreaks in which the exposure occurred in more than one state. Information reported includes dates of the outbreak; number of illnesses, hospitalizations, and deaths; states and territories involved; etiologic agent; and food involved (2).

Foods were categorized according to methods developed by the Interagency Food Safety Analytics Collaboration (3), a partnership between CDC, the Food and Drug Administration (FDA), and the Department of Agriculture's Food Safety and Inspection Service (USDA-FSIS).

\section{Results}

During 2010-2014, 120 multistate foodborne disease outbreaks were reported to the Foodborne Disease Outbreak Surveillance System. An average of 24 outbreaks occurred per year (range $=19-26)$. The median number of states involved in each outbreak was six (range $=2-37$ ). All states, 
the District of Columbia, and Puerto Rico were affected by one or more multistate foodborne disease outbreaks during the 5-year period. The median number of cases per outbreak was 22 (range $=2-1,939)$. Overall, these multistate outbreaks accounted for 3\% (120 of 4,163) of all U.S. foodborne disease outbreaks, but they were responsible for $11 \%(7,929$ of $71,747)$ of illnesses, $34 \%$ (1,460 of 4,247) of hospitalizations, and $56 \%$ (66 of 118) of deaths in foodborne outbreaks. The leading etiologic agents in multistate foodborne outbreaks were Salmonella (63 outbreaks), Shiga toxin-producing E. coli (STEC) (34), and Listeria monocytogenes (12) (Table 1).

Salmonella accounted for the majority of illnesses (82\%; $6,530$ of 7,929$)$ and hospitalizations $(65 \%$; 952 of 1,460$)$ associated with multistate foodborne disease outbreaks (Table 2), and was responsible for the three largest outbreaks, which were linked to eggs (an estimated 1,939 illnesses), chicken (634), and a raw scraped ground tuna product (425). Salmonella outbreaks involved nearly twice as many food categories as any other pathogen, including fruit (13 outbreaks; $21 \%$ ), the most frequent category, followed by seeded vegetables (nine outbreaks), nuts and seeds (eight), and sprouts (seven). Foods from land animals, such as beef (five outbreaks), chicken (four), and eggs (one), also were sources of multistate Salmonella outbreaks (Table 1). The three most common Salmonella serotypes were Newport (10 outbreaks; 16\%), Enteritidis (six; 10\%), and Javiana (five; $8 \%$ ).

Among the 34 STEC outbreaks, almost half (14 outbreaks; $41 \%)$ were linked to vegetable row crops (e.g., leafy greens) and another quarter (8 outbreaks; $24 \%$ ) to beef. Dairy products (two outbreaks), sprouts (two), and fish (one) also were reported (Table 1). Twenty (59\%) of the multistate STEC outbreaks were caused by serogroup O157. Serogroups O26 and $\mathrm{O} 145$ were responsible for three outbreaks each.

Listeria monocytogenes caused 12 multistate outbreaks. Six resulted from contaminated dairy products, three from contaminated fruit, and one from sprouts (Table 1). Listeria was the most deadly pathogen among those isolated in multistate foodborne disease outbreaks, accounting for 57 deaths, 86\% of the total. Thirty-three $(58 \%)$ of the deaths occurred in a single outbreak linked to cantaloupe.

Eighteen (15\%) outbreaks were linked to imported foods (Table 3). These outbreaks accounted for 18\% (1,439 of 7,929) of illnesses, $21 \%$ (300 of 1,460) of hospitalizations, and $9 \%$ (6 of 66) of deaths. Mexico was the leading source of imported food linked to multistate outbreaks (six), followed by Turkey (three). Six of the outbreaks caused by imported food $(35 \%)$ were linked to fruit, four to nuts and seeds, and two each to fish and seeded vegetables. Salmonella was the etiologic agent for 15 (83\%) outbreaks. The only multistate
TABLE 1. Multistate foodborne disease outbreaks ( $N=120)$, by pathogen and food category - Foodborne Disease Outbreak Surveillance System, United States, 2010-2014

\begin{tabular}{|c|c|c|c|c|c|c|c|}
\hline \multirow{3}{*}{$\begin{array}{l}\text { Food } \\
\text { category }\end{array}$} & \multicolumn{7}{|c|}{ Pathogen } \\
\hline & \multirow[b]{2}{*}{ Salmonella } & \multirow[b]{2}{*}{ STEC* } & \multirow[b]{2}{*}{ Listeria } & \multirow[b]{2}{*}{ Vibrio } & \multirow[b]{2}{*}{ Other $^{\dagger}$} & \multicolumn{2}{|c|}{ Total } \\
\hline & & & & & & No. & (\%) \\
\hline Fruits & 13 & - & 3 & - & 1 & 17 & (14) \\
\hline $\begin{array}{l}\text { Vegetable } \\
\text { row crops }\end{array}$ & 1 & 14 & - & - & - & 15 & (13) \\
\hline Beef & 5 & 8 & - & - & - & 13 & (11) \\
\hline Sprouts & 7 & 2 & 1 & - & - & 10 & (8) \\
\hline $\begin{array}{l}\text { Seeded } \\
\text { vegetables }\end{array}$ & 9 & - & - & - & - & 9 & (8) \\
\hline Dairy & - & 2 & 6 & - & - & 8 & (7) \\
\hline Nuts/Seeds & 8 & 1 & - & - & - & 9 & (8) \\
\hline Mollusks & - & - & - & 6 & 1 & 7 & (6) \\
\hline Chicken & 4 & - & - & - & 1 & 5 & (4) \\
\hline Fish & 3 & 1 & - & - & - & 4 & (3) \\
\hline Turkey & 3 & - & - & - & - & 3 & (3) \\
\hline Eggs & 1 & - & - & - & - & 1 & $(<1)$ \\
\hline Game & - & 1 & - & - & - & 1 & $(<1)$ \\
\hline Oils/Sugars & 1 & - & - & - & - & 1 & $(<1)$ \\
\hline Pork & 1 & - & - & - & - & 1 & $(<1)$ \\
\hline Other $\S$ & 7 & 5 & 2 & - & 2 & 16 & (13) \\
\hline Total (\%) & $63(53)$ & $34(28)$ & $12(10)$ & $6(5)$ & $5(4)$ & 120 & (100) \\
\hline
\end{tabular}

*Shiga toxin-producing E. coli.

†Includes one outbreak each caused by Campylobacter, a chemical, Cyclospora, Hepatitis A virus, and norovirus.

$\S$ Includes multiple foods (seven outbreaks), uncategorized food (four), and unknown food (five).

TABLE 2. Number of outbreaks, illnesses, hospitalizations, and deaths associated with multistate foodborne disease outbreaks $(N=120)$ - Foodborne Disease Outbreak Surveillance System, United States, 2010-2014

\begin{tabular}{|c|c|c|c|c|c|c|c|c|}
\hline \multirow[b]{2}{*}{ Pathogen } & \multicolumn{2}{|c|}{ Outbreaks } & \multicolumn{2}{|c|}{ Illnesses } & \multicolumn{2}{|c|}{ Hospitalizations } & \multicolumn{2}{|c|}{ Deaths } \\
\hline & No. & (\%) & No. & (\%) & No. & (\%) & No. & (\%) \\
\hline Salmonella & 63 & (53) & 6,530 & (82) & 952 & (65) & 8 & (12) \\
\hline STEC* & 34 & (28) & 636 & (8) & 178 & (12) & 1 & (2) \\
\hline Listeria & 12 & (10) & 271 & (3) & 244 & (17) & 57 & (86) \\
\hline Vibrio & 6 & (5) & 89 & (1) & 6 & $(<1)$ & 0 & (0) \\
\hline Other $^{\dagger}$ & 5 & (4) & 403 & (5) & 80 & (5) & 0 & (0) \\
\hline Total (\%) & 120 & (100) & 7,929 & (100) & 1,460 & (100) & 66 & (100) \\
\hline
\end{tabular}

foodborne outbreak attributed to a parasite (Cyclospora) was associated with a bagged salad mix imported from Mexico.

During 2010-2014, investigators conducted product tracebacks for 87 of the multistate outbreaks (73\%). The tracebacks led to food product recalls in 55 outbreaks (46\%).

\section{Conclusions and Comment}

Multistate foodborne outbreaks were responsible for a disproportionate number of outbreak-associated hospitalizations and deaths compared with single state outbreaks in the United States during 2010-2014. The pathogens that caused most 
TABLE 3. Multistate foodborne diseases outbreaks $(\mathrm{N}=18)$ from imported foods, by selected characteristics — Foodborne Disease Outbreak Surveillance System, United States, 2010-2014

\begin{tabular}{|c|c|c|c|c|c|c|c|c|}
\hline Year & Country of origin & Pathogen & Food category & Food & $\begin{array}{l}\text { No. of } \\
\text { states }\end{array}$ & $\begin{array}{l}\text { No. of } \\
\text { illnesses }\end{array}$ & $\begin{array}{c}\text { No. of } \\
\text { hospitalizations }\end{array}$ & $\begin{array}{l}\text { No. of } \\
\text { deaths }\end{array}$ \\
\hline 2010 & Guatemala & Salmonella & Fruits & Mamey shake & 3 & 12 & 9 & 0 \\
\hline 2010 & Unknown & Salmonella & Fish & Ahi tuna & 12 & 51 & Unknown & Unknown \\
\hline 2011 & Guatemala & Salmonella & Fruits & Cantaloupe & 10 & 20 & 3 & 0 \\
\hline 2011 & Lebanon & Salmonella & Nuts/Seeds & Hummus & 8 & 23 & 0 & 0 \\
\hline 2011 & Mexico & Salmonella & Fruits & Papaya & 25 & 106 & 10 & 0 \\
\hline 2011 & Turkey & Salmonella & Nuts/Seeds & Pine nuts & 6 & 53 & 2 & 0 \\
\hline 2012 & India & Salmonella & Fish & Scraped ground tuna & 29 & 425 & 55 & 0 \\
\hline 2012 & Italy & Listeria & Dairy & Ricotta cheese & 14 & 23 & 21 & 5 \\
\hline 2012 & Mexico & Salmonella & Fruits & Mango & 15 & 129 & 33 & 0 \\
\hline 2013 & Mexico & Cyclospora & No category* & Bagged salad mix & 2 & 161 & 10 & 0 \\
\hline 2013 & Mexico & Salmonella & Seeded vegetables & Cucumber & 18 & 84 & 17 & 0 \\
\hline 2013 & Turkey & Salmonella & Nuts/Seeds & Tahini & 10 & 17 & 1 & 1 \\
\hline 2013 & Turkey & Hepatitis A virus & Fruits & Pomegranate seeds & 10 & 157 & 69 & 0 \\
\hline 2013 & Vietnam & Salmonella & Oils/Sugars & Sugarcane & 2 & 7 & 1 & 0 \\
\hline 2014 & Canada & Salmonella & Nuts/Seeds & Chia seed powder & 16 & 31 & 5 & 0 \\
\hline 2014 & China & Salmonella & Sprouts & Mung bean sprouts & 12 & 115 & 19 & 0 \\
\hline 2014 & Mexico & Salmonella & Fruits & Mango & 4 & 4 & 1 & 0 \\
\hline 2014 & Mexico & Salmonella & Seeded vegetables & Sweet mini peppers & 10 & 21 & 5 & 0 \\
\hline
\end{tabular}

* The outbreak was not attributed to a single food.

of the multistate outbreaks (Salmonella, STEC, and Listeria monocytogenes) are more likely to cause severe disease and death than the leading cause of single state outbreaks, norovirus, which typically causes a milder illness (4). Rapid identification of the food that caused the outbreak, discovering where the contamination occurred along a complex supply chain, and recalling a food distributed across the country and perhaps around the world are challenging tasks. Public health departments and government agencies can work more closely with the food industries, which understand how their foods are produced and distributed, to speed up multistate state foodborne disease outbreak and traceback investigations. Lessons learned from these investigations can inform industry and government efforts to improve food safety practices.

Focusing on foods that are prominent in multistate outbreaks can guide industry and government in targeting interventions. The finding that many multistate outbreaks were caused by contaminated produce suggests a need for strengthening produce safety. Stronger safety measures in the production of fruits and vegetables are a key provision in the Food Safety Modernization Act (FSMA), enacted in 2011. FSMA granted FDA, the federal agency responsible for oversight of produce safety, new powers to improve the safe production and harvesting of produce by creating standards for environmental factors including staff hygiene, microbial levels in agricultural water, uses of animal waste in growing foods, and equipment sanitation (5).

A second important area for improving food safety is through enhanced ability to monitor the quality and to improve traceability of imported foods. Tracking suspected foods to their source is often arduous for domestic products, and is even more difficult for imported products, in part because of different food traceability standards in other countries. In addition, U.S. food safety laws and regulations are difficult to enforce for foods produced in foreign countries. FSMA addresses these issues by granting FDA, which is responsible for monitoring most imported foods, new import authorities and mandates, including importer food safety accountability, third-party certification of food safety compliance for high-risk foods, and increased authority to refuse entry of imported foods ( $G$ ).

Industry-led best practices also help improve food safety and can be informed by lessons learned from outbreaks. For example, the Beef Industry Food Safety Council was created in 1997 following a large STEC outbreak caused by contaminated beef a few years earlier. The council endorses the principle that "food safety is a noncompetitive issue" and that best practices should be shared throughout the industry (7). The California Leafy Green Products Handler Marketing Agreement was drafted by California farmers after a 2006 STEC O157 outbreak linked to produce and consists of best practices to ensure leafy green vegetable safety. Members also consent to audits by USDA-certified inspectors throughout the growing season (8). Industry best practices can complement food safety laws and regulations and help ensure that foods remain safe during growing, processing, and shipping.

Regulations, performance standards, and adherence to industry-developed best practices can improve food safety but are not a guarantee that food products will be contaminantfree; even in highly sanitary environments, contamination can occur. When an outbreak occurs, local, state, and federal investigators need state-of-the-art tools, such as whole genome sequencing (which is expected to replace current PulseNet subtyping methods over the next few years) and electronic 
platforms for data sharing, to identify the suspected food item and trace it to its source. Rapidly determining common food exposures among patients, often in distant localities, is the key, yet patients sometimes have difficulty remembering the foods they have eaten and when and where they purchased these foods. Therefore, investigators are collaborating with retailers to use data from loyalty cards (i.e., shopper cards) and store membership programs to obtain specific purchase date and brand information on products that consumers purchased before their illness (9). Investigators also seek out clusters of illnesses within an outbreak among persons who reported eating at the same restaurant location, attending the same event, or shopping at the same grocery store because these clusters can provide critical clues about the source of an outbreak. Once a specific food is identified, detailed records are essential to trace it back to the processing plant, the producer, or the farm. Without such records, outbreak investigators might not be able to identify the ultimate source of the contaminated food, even when they have identified the food itself (10).

When industry and government agencies collaborate, they not only speed up outbreak investigation and traceback processes but also can use lessons learned to reduce the likelihood of future outbreaks. For example, during 2013-2014, investigators linked an outbreak of 634 Salmonella serotype Heidelberg infections to handling or consuming chicken from a single producer (11). Despite the large number of reported infections, they likely represent only a small fraction of the actual number of infected persons, as with all foodborne disease outbreaks (1). Public health agencies worked with the involved industry to identify the ultimate sources of the outbreak and to implement control measures. The affected company has since established new hygiene requirements at its farms and processing plants and in its product transportation practices (12). In January 2015, in part in response to this outbreak, USDAFSIS proposed new production facility performance standards intended to reduce Salmonella and Campylobacter contamination of chicken and turkey parts (13). These standards are part of the larger body of USDA-FSIS guidance aimed at improving food safety in the meat, poultry, and egg industries (14). The development and implementation of industry best practices and standards, coupled with regulations that enable a rapid public health response can help enhance food safety and prevent future multistate foodborne disease outbreaks in the United States.

\section{Acknowledgment}

Kelly A. Walsh, MPH, Division of Foodborne, Waterborne, and Environmental Diseases, National Center for Emerging and Zoonotic Infectious Diseases, CDC.

\section{Key Points}

- Multistate foodborne outbreaks are being identified more often in the United States because of better surveillance. Greater centralization of food processing and distribution practices could be increasing the frequency and size of multistate foodborne outbreaks.

- From 2010 through 2014, multistate foodborne outbreaks accounted for only $3 \%$ of all U.S. foodborne outbreaks detected, but caused over one third of the hospitalizations and more than half of the deaths.

- Salmonella, Shiga toxin-producing Escherichia coli, and Listeria monocytogenes were the leading pathogens causing multistate foodborne outbreaks. In order of frequency, fruits, vegetable row crops, beef, sprouts, and seeded vegetables were the leading contaminated foods.

- Food industries can effectively prevent or limit the size of outbreaks by making food safety a core part of company culture and by meeting or exceeding new food safety regulations and standards. Companies can maintain records that enable rapid tracing of foods from source to destination and use only those suppliers that use food safety best practices. Store loyalty cards can help identify foods that caused illness and enable more rapid notification of customers who bought a specific product.

- Additional information is available at http://www.cdc. gov/vitalsigns.

${ }^{1}$ Epidemic Intelligence Service, CDC; ${ }^{2}$ Division of Foodborne, Waterborne, and Environmental Diseases, National Center for Emerging and Zoonotic Infectious Diseases, CDC.

Corresponding author: Samuel Crowe, sjcrowe@cdc.gov, 404-639-0195.

\section{References}

1. Scallan E, Hoekstra RM, Angulo FJ, et al. Foodborne illness acquired in the United States - major pathogens. Emerg Infect Dis 2011;17:7-15.

2. CDC. Foodborne outbreak tracking and reporting: surveillance for foodborne disease outbreaks. Atlanta, GA: US Department of Health and Human Services, CDC; 2013. Available at http://www.cdc.gov/foodsafety/ fdoss/surveillance/index.html.

3. CDC. Interagency Food Safety Analytics Collaboration (IFSAC). Atlanta, GA: US Department of Health and Human Services, CDC; 2014. Available at http://www.cdc.gov/foodsafety/ifsac/index.html.

4. Nguyen VD, Bennett SD, Mungai E, Gieraltowski L, Hise K, Gould LH. Increase in multistate foodborne disease outbreaks-United States, 1973-2010. Foodborne Pathog Dis 2015; [Epub ahead of print].

5. Food and Drug Administration. FSMA proposed rule for produce safety. Silver Spring, MD: US Department of Health and Human Services, Food and Drug Administration; 2013. Available at http://www.fda.gov/Food/ GuidanceRegulation/FSMA/ucm334114.htm. 
6. Food and Drug Administration. Imports. Silver Spring, MD: US Department of Health and Human Services, Food and Drug Administration; 2015. Available at http://www.fda.gov/Food/ GuidanceRegulation/FSMA/ucm257980.htm.

7. Beef Industry Food Safety Council. The Beef Industry Food Safety Council (BIFSCo). Available at http://www.explorebeef.org/CMDocs/ ExploreBeef/bifsco350.pdf.

8. California leafy green products handler marketing agreement: about us. Available at http://www.lgma.ca.gov/about-us/.

9. Gieraltowski L, Julian E, Pringle J, et al. Nationwide outbreak of Salmonella Montevideo infections associated with contaminated imported black and red pepper: warehouse membership cards provide critical clues to identify the source. Epidemiol Infect 2013;141:1244-52.

10. Schneider JL, White PL, Weiss J, et al. Multistate outbreak of multidrugresistant Salmonella newport infections associated with ground beef, October to December 2007. J Food Prot 2011;74:1315-9.
11. CDC. Multistate outbreak of multidrug-resistant Salmonella Heidelberg infections linked to Foster Farms brand chicken (final update). Atlanta, GA: US Department of Health and Human Services, CDC; 2014. Available at http://www.cdc.gov/salmonella/heidelberg-10-13/index.html.

12. Foster Farms. Our comprehensive food safety program. Available at http://fosterfarms.com/fosterfarmsfoodsafety/.

13. Federal Register. Changes to the Salmonella and Campylobacter verification testing program: proposed performance standards for Salmonella and Campylobacter in not-ready-to-eat comminuted chicken and turkey products and raw chicken parts and related agency verification procedures and other changes to agency sampling. Vol. 80, No. 16, 2015.

14. Food Safety and Inspection Service. Compliance guides index. Washington, DC: US Department of Agriculture; 2015. Available at http://www.fsis.usda.gov/wps/portal/fsis/topics/regulatory-compliance/ compliance-guides-index. 


\section{Primary Amebic Meningoencephalitis Associated with Hot Spring Exposure During International Travel — Seminole County, Florida, July 2014}

\author{
Peggy J. Booth ${ }^{1}$; Dean Bodager MPA ${ }^{2}$; Tania A. Slade, $\mathrm{MPH}^{1}$;
} Swannie Jett, $\mathrm{DrPH}^{1}$

On July 2, 2014, the Florida Department of Health was notified of a suspected case of primary amebic meningoencephalitis (PAM). PAM is a rare, devastating infection of the brain caused by Naegleria fowleri, a free-living ameba found in warm, fresh water bodies throughout the world. Amebae are aspirated into the nasal cavity through swimming, splashing, or nasal irrigation, and after attaching to the nasal mucosa, migrate across the cribriform plate to the brain via the olfactory nerves, causing extensive damage to the frontal lobes of the brain (1). In August 2013, miltefosine, an antiparasitic drug with activity against $N$. fowleri, became available from CDC as an investigational drug used for the treatment of free-living ameba infections in combination with other antimicrobial drugs (2).

On June 27, 2014, the patient, a boy aged 11 years, had experienced a headache, low grade fever, stiff neck, nausea, and vomiting. He was hospitalized on June 29, with a presumptive diagnosis of viral meningitis. The initial cerebral spinal fluid (CSF) analysis was negative for motile ameba. All other routine tests were negative. His condition deteriorated, progressing to altered mental status, slurred speech, and seizures. On July 1 the patient required intubation and mechanical ventilation. A second CSF specimen was collected in the evening of July 1 , and motile ameba were observed and reported in the early morning of July 2. Physician consultation with CDC was immediately facilitated by the Florida Department of Health to arrange for the release and delivery of miltefosine from Atlanta, Georgia, to Orlando, Florida; however, the patient died before its arrival on July 2. On July 9, CDC confirmed the presence of $N$. fowleri in the CSF by real-time polymerase chain reaction.

An interview of the patient's parents conducted by the Florida Department of Health in Seminole County revealed that the family had traveled to Costa Rica during June 19June 27, 2014, where they had engaged in swimming, zip lining, and water slide use at a resort hot springs on June 23. The parents reported having avoided exposure to bodies of fresh water in Florida, because of public awareness of $N$. fowleri, but said they were unaware of the risk for PAM internationally. No other swimming or nasal insufflation of water was reported either in Costa Rica or in Florida during the week before illness onset. $N$. fowleri was detected in water samples from the hot springs and river pond located at the resort (3).
PAM is typically fatal; only three nonfatal cases have ever been reported in the United States (4). Miltefosine was administered as part of the successful treatment of a case of PAM in 2013 (5). Miltefosine can be requested from CDC upon clinical suspicion of PAM infection and before laboratory confirmation. Physicians should consider a diagnosis of PAM in persons with a clinically compatible illness who have a history of fresh water exposure 1-9 days before illness onset. Early diagnosis and prompt treatment are thought to be essential because of the high mortality rate. Strategic placement of miltefosine in Texas and Florida, where approximately half of all cases in the United States have been reported, is being considered and might reduce the time to initiating treatment associated with transport of the medication, thereby increasing the possibility of patient survival. Health care professionals and the public need to be aware that $N$. fowleri can be found in any warm, fresh water body throughout the world, including latitudes in the northern United States previously thought to have a climate incompatible with ameba activity (G).

\section{Acknowledgments}

Donna Walsh, Gladys Fernando, Florida Department of Health, Seminole County; Benjamin G. Klekamp, Debra Mattas, Dain Weister, Mirna Chamorro, Florida Department of Health, Orange County; David Atrubin, Jamie DeMent, Division of Disease Control and Health Protection, Florida Department of Health; Ibne Ali, Jonathan Jackson, CDC.

${ }^{1}$ Florida Department in Health-Seminole County; ${ }^{2}$ Florida Department of Health.

Corresponding author: Tania Slade, Tania.Slade@flhealth.gov, 407-665-3266.

\section{References}

1. Visvesvara GS. Free-living amebae as opportunistic agents of human disease. J Neuroparasitology 2010;1:61-73. Available at http://www. ashdin.com/journals/jnp/N100802.pdf.

2. CDC. Investigational drug available directly from CDC for the treatment of infections with free-living amebae. MMWR Morb Mortal Wkly Rep 2013;62:666.

3. Abrahams-Sandi E, Retana-Moreira L, Castro-Castillo A, Reyes-Batlle M, Lorenzo-Morales J. Fatal meningoencephalitis in child and isolation of Naegleria fowleri from hot springs in Costa Rica. Emerg Infect Dis 2015;21:382-4.

4. CDC. Naegleria fowleri-primary amebic meningoencephalitis (PAM). Atlanta, GA: US Department of Health and Human Services, CDC; 2014. Available at http://www.cdc.gov/parasites/naegleria/illness.html.

5. Linam WM, Ahmed M, Cope JR, et al. Successful treatment of an adolescent with Naegleria fowleri primary amebic meningoencephalitis. Pediatrics 2015;135:e744-8.

6. Kemble SK, Lynfield R, DeVries AS, et al. Fatal Naegleria fowleri infection acquired in Minnesota: possible expanded range of a deadly thermophilic organism. Clin Infect Dis 2012;54:805-9. 


\section{World Pneumonia Day — November 12, 2015}

November 12, 2015, is the seventh annual World Pneumonia Day, observed to raise awareness and promote interventions to protect against, treat, and prevent pneumonia, which continues to be a global public health concern. Each year approximately 900,000 children aged $<5$ years die from pneumonia worldwide; $70 \%$ of childhood pneumonia hospitalizations in the United States are in this age group $(1,2)$. Pneumonia is also a leading infectious cause of hospitalization and death among U.S. adults, resulting in $>\$ 10$ billion in hospital expenses in 2011 (3). Preventing future pneumonia-related deaths and illnesses among children and adults globally depends on vaccination against some of the pathogens that cause pneumonia; reductions in medical conditions and behaviors, such as smoking, that increase the risk for pneumonia; improved diagnostic tests; and appropriate antimicrobial therapy and supportive care.

Ongoing research on diagnostics, prevention, and treatment, better access to existing tools, as well as the concerted efforts of national governments, the international community, civil society, and the private sector to guide policy and funding, are also important.

To strengthen surveillance efforts CDC is joining with other U.S. government agencies and global partners to advance a Global Health Security Agenda (additional information available at http://www.globalhealth.gov/global-health-topics/ global-health-security/GHS\%20Agenda.pdf). Additional information about World Pneumonia Day is available at http:// worldpneumoniaday.org, including the new Pneumonia and Diarrhea Progress Report 2015.

\section{References}

1. Liu L, Oza S, Hogan D, et al. Global, regional, and national causes of child mortality in 2000-13, with projections to inform post-2015 priorities: an updated systematic analysis. Lancet 2015;385:430-40.

2. Jain S, Williams DJ, Arnold SR, et al. Community-acquired pneumonia requiring hospitalization among U.S. children. N Engl J Med 2015;372:835-45.

3. Pfunter A, Wier LM, Steiner C. Costs for hospital stays in the United States, 2011 (Statistical Brief No. 168). Rockville, MD: Agency for Healthcare Research and Quality, Healthcare Cost and Utilization Project; 2013. 


\section{Average Age* at Death ${ }^{\dagger}$ from HIV Disease, ${ }^{\S}$ by Sex - United States, 1987-2013}

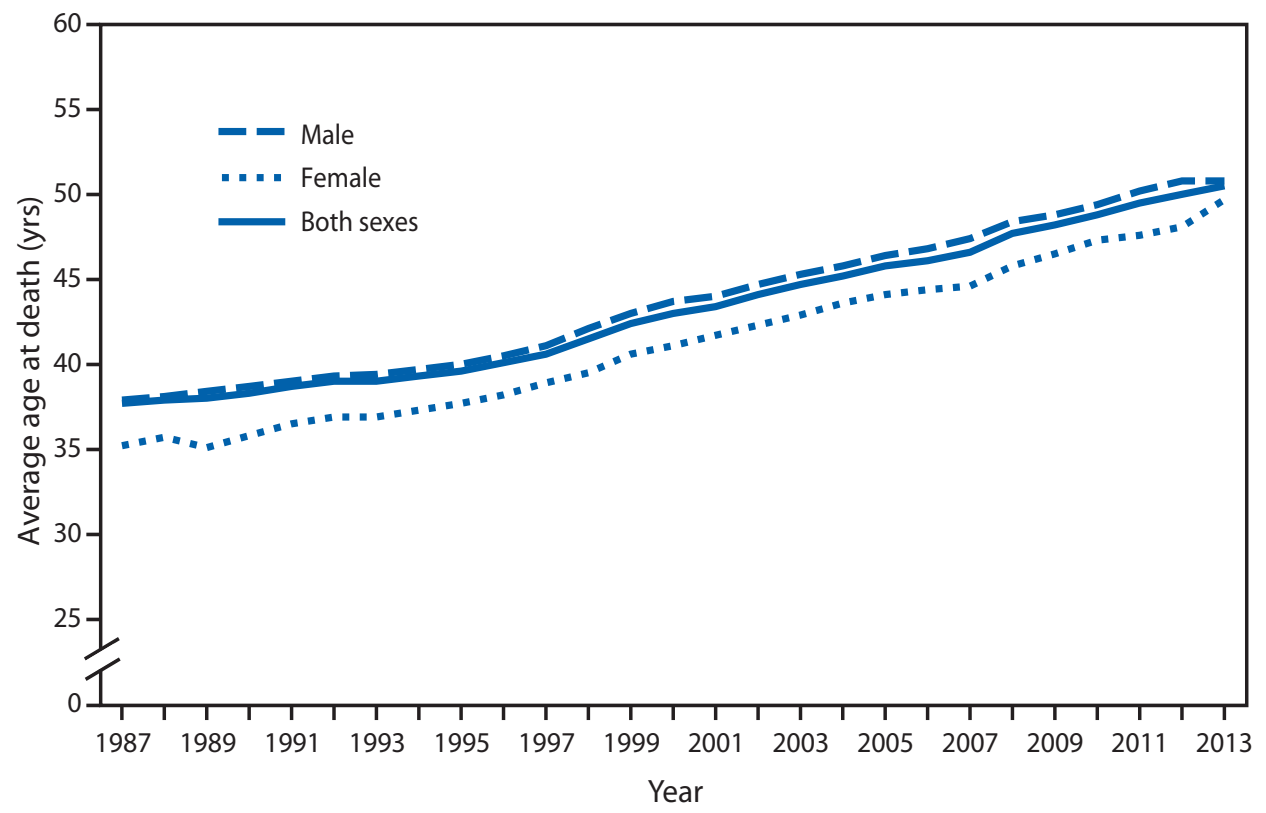

Abbreviation: HIV = human immunodeficiency virus.

* The average age at death is the sum of age at death for all HIV deaths, divided by the total number of HIV deaths.

${ }^{\dagger}$ Records with age not stated were not included.

$\S$ Deaths from HIV disease are identified using underlying causes of death with codes 042-044 (1987-1998) and B20-B24 (1999-2013) in the International Classification of Disease, Ninth and Tenth revisions.

During 1987-2013, the average age at death from HIV disease increased steadily for both males and females. The average age at death increased $34.0 \%$ among males, from 37.9 years in 1987 to 50.8 years in 2013 . Among females, the average age at death increased $41.2 \%$, from 35.2 years in 1987 to 49.7 years in 2013. Throughout the period, the average age at death from HIV disease for males was higher than that for females.

Source: National Vital Statistics System. U.S. mortality data files, 1987-2013. Available at http://www.cdc.gov/nchs/data_access/vitalstatsonline.htm. Reported by: Jiaquan Xu, MD, jax4@cdc.gov, 301-458-4086. 



The Morbidity and Mortality Weekly Report (MMWR) Series is prepared by the Centers for Disease Control and Prevention (CDC) and is available free of charge in electronic format. To receive an electronic copy each week, visit MMWR's free subscription page at http://www.cdc.gov/mmwr/mmwrsubscribe.html. Paper copy subscriptions are available through the Superintendent of Documents, U.S. Government Printing Office, Washington, DC 20402; telephone 202-512-1800.

Readers who have difficulty accessing this PDF file may access the HTML file at http://www.cdc.gov/mmwr/index2015.html. Address all inquiries about the MMWR Series, including material to be considered for publication, to Executive Editor, MMWR Series, Mailstop E-90, CDC, 1600 Clifton Rd., N.E., Atlanta, GA 30329-4027 or to mmwrq@cdc.gov.

All material in the MMWR Series is in the public domain and may be used and reprinted without permission; citation as to source, however, is appreciated. Use of trade names and commercial sources is for identification only and does not imply endorsement by the U.S. Department of Health and Human Services.

References to non-CDC sites on the Internet are provided as a service to $M M W R$ readers and do not constitute or imply endorsement of these organizations or their programs by CDC or the U.S. Department of Health and Human Services. CDC is not responsible for the content of these sites. URL addresses listed in $M M W R$ were current as of the date of publication.

ISSN: 0149-2195 (Print) 